Portland State University

PDXScholar

$1-1-2012$

\title{
Finding the Past in the Present: Modeling Prehistoric Occupation and Use of the Powder River Basin, Wyoming
}

Catherine Anne Clark

Portland State University

Follow this and additional works at: https://pdxscholar.library.pdx.edu/open_access_etds Let us know how access to this document benefits you.

\section{Recommended Citation}

Clark, Catherine Anne, "Finding the Past in the Present: Modeling Prehistoric Occupation and Use of the Powder River Basin, Wyoming" (2012). Dissertations and Theses. Paper 587.

https://doi.org/10.15760/etd.587

This Thesis is brought to you for free and open access. It has been accepted for inclusion in Dissertations and Theses by an authorized administrator of PDXScholar. Please contact us if we can make this document more accessible: pdxscholar@pdx.edu. 
Finding the Past in the Present:

Modeling Prehistoric Occupation and Use of the Powder River Basin, Wyoming

\author{
by \\ Catherine Anne Clark
}

A thesis submitted in partial fulfillment of the requirements for the degree of

Master of Science
in
Geography

Thesis Committee:

Barbara Brower, Chair

Jiunn-Der Duh

Ken Ames

David Banis

Portland State University

(C)2012 


\begin{abstract}
In the Powder River Basin of Wyoming, our nation's interest in protecting its cultural heritage collides with the high demand for carbon fuels. "Clinker" deposits dot the basin. These distinctive buttes, created by the underground combustion of coal, are underlain by coal veins; they also provided the main lithic resources for prehistoric hunter-gatherers. These deposits signify both a likelihood of extractable carbon and high archaeological site density. Federal law requires that energy developers must identify culturally significant sites before mining can begin. The research presented here explains the need for and describes a statistical tool with the potential to predict sites where carbon and cultural resources co-occur, thus streamlining the process of identifying important heritage sites to protect them from adverse impacts by energy development. The methods used for this predictive model include two binary logistic regression models using known archaeological sites in the Powder River Basin. The model as developed requires further refinement; the results are nevertheless applicable to future research in this and similar areas, as I discuss in my conclusion.
\end{abstract}




\section{Acknowledgements}

Thank you to the committee for long hours of reading, editing and discussing, Barbara Brower, Geoffrey Duh, David Banis and Ken Ames. Geoffrey and David hopefully after this I'll never have to ask a "quick question" again.

A sincere thank you as well to my family and friends, particularly Linda Clark, Larry and Jill Clark, Kathy and Chas Hrastar, Willow Campbell, Nadia and Adam Jones, Cale Garrett, and Camille Cope.

Nothing would get done in the Geography Department without Karin Waller, and to her I owe a very sincere apology for all the paperwork I have cajoled her into doing for me and for all the guidance I desperately needed.

Thanks to all those at work that didn't let me forget I hadn't completed my degree yet - Randy Ni, James Sharpe, Keith Mendez, Jenni Gutzeit, David Sheldon, Ginny Jenkins, and Heather Hay. The reminders of my lack of degree were the driving force I needed.

My biggest, sincerest thank you to Scott Wagers, for proposing this project as a viable graduate research subject and answering innumerable questions about clinker deposits, the Powder River Basin and prehistory. Thank you for sharing your thoughts and your time. 


\section{Contents}

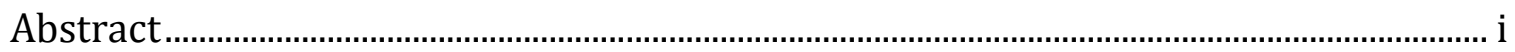

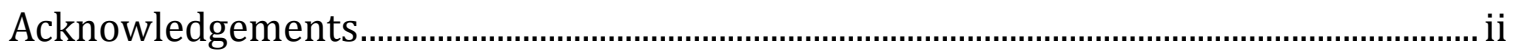

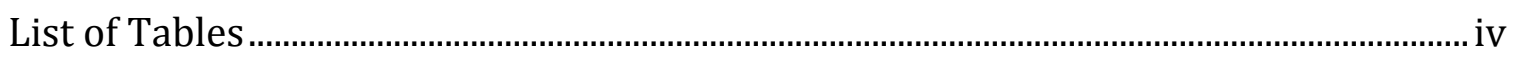

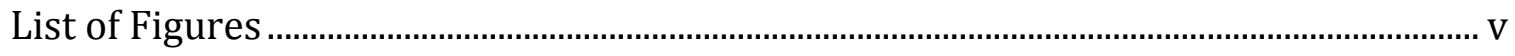

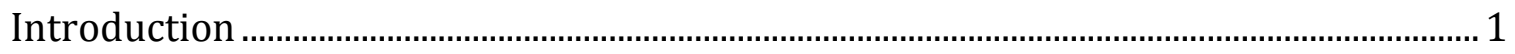

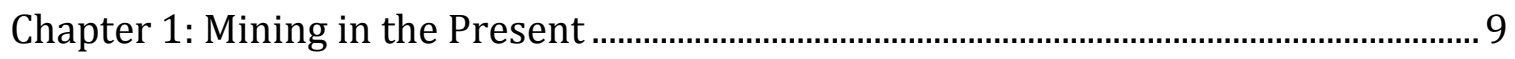

Chapter 2: Hunting and Gathering in the Past: The Early Occupation of the PRB..... 13

Chapter 3: Cultural Resource Management Law................................................................. 20

Chapter 4: Case Demonstration - A Predictive Model for Delineating the Probable Concentrations of Cultural Resources................................................................. 28

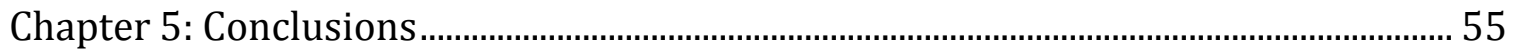

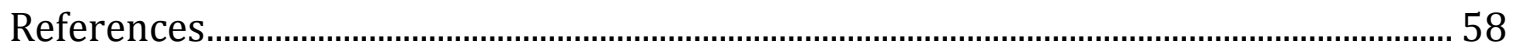




\section{List of Tables}

Table 1: Sample of Literature on Predictive Modeling and Archaeology ...................... 29

Table 2: Binary Logistic Regression Results ..................................................................... 48

Table 3: Site Types and Binary Logistic Regression Results............................................... 48

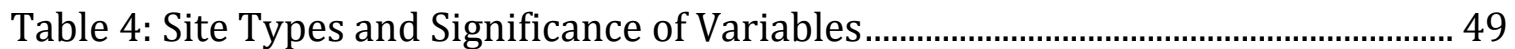

Table 5: Example of Wyoming SHPO Database Organization ........................................... 53 


\section{List of Figures}

Figure 1: Powder River Basin, Montana and Wyoming ....................................................... 2

Figure 2: Surface and Mineral Ownership In The PRB ………………………………..... 4

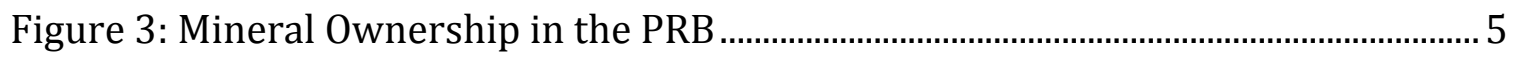

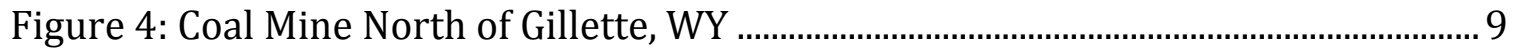

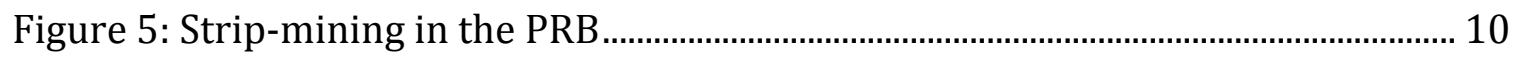

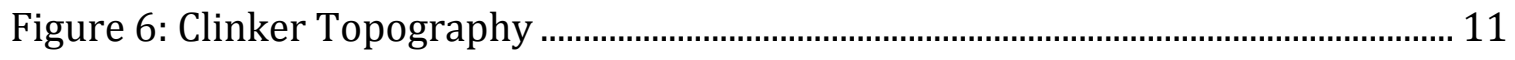

Figure 7: Powder River Basins and Sub-basins .................................................................. 34

Figure 8: Surveyed Areas within the Study Area ............................................................. 35

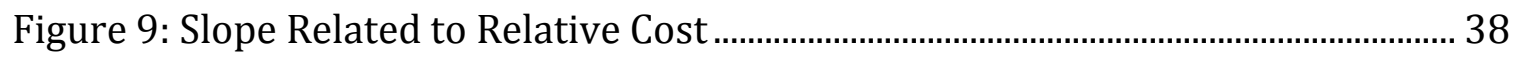

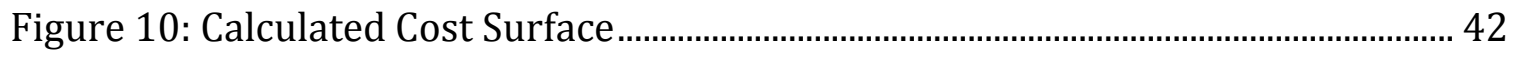

Figure 11: Cost Distance To Clinker Deposits .......................................................................... 44

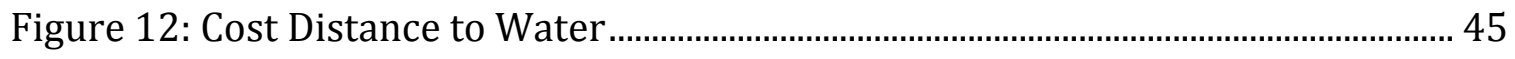

Figure 13: Combination Cost Distances to Clinker and Water.......................................... 46 


\section{Introduction}

The Powder River Basin (PRB), located in northern-central Wyoming and south-central Montana, is a landscape of hills and drainages in the center of the Northern Great Plains. The basin, covering $56,000 \mathrm{~km}^{2}\left(21,620 \mathrm{mi}^{2}\right)$ is bounded on the west by the Big Horn Mountains, the tallest peak rising more than 3,960 meters $(13,000$ feet $)$. To the east stand Devil's Tower and the Black Hills of South Dakota, and to the south are the Laramie Mountains and the Pumpkin Buttes (Figure 1).

Three major rivers run through the PRB: the Tongue, the Yellowstone, and the Powder, which joins the Missouri River to the north. The climate is semi-arid, cold continental, with dry winters and warm summers (McNab and Avers 1994). The basin, part of the Northern Great Plains ecoregion, is categorized as steppe; the vegetation includes mixed-grass prairie, coniferous woodlands, wetlands, riparian forests, and shrub steppe. Elevations range between 915 and 1830 meters above sea level (3,000 and 6,000 feet) within the basin itself; landforms include sedimentary plains, eroded badlands, island mountain ranges, and scattered buttes (McNab and Avers 1994). Most buttes of the Powder River Basin are formed from clinker, a reddish rock baked and hardened from beneath by underground coal fires common in this region because of the underlying geology. Highly resistant to erosion, the clinker deposits create imposing features on the landscape, occupy roughly 4,100 $\mathrm{km}^{2}\left(1,580 \mathrm{mi}^{2}\right)(7 \%)$ of the area of the PRB, and are a key element in the conflict to be explored here (Heffern et al. 2007). 


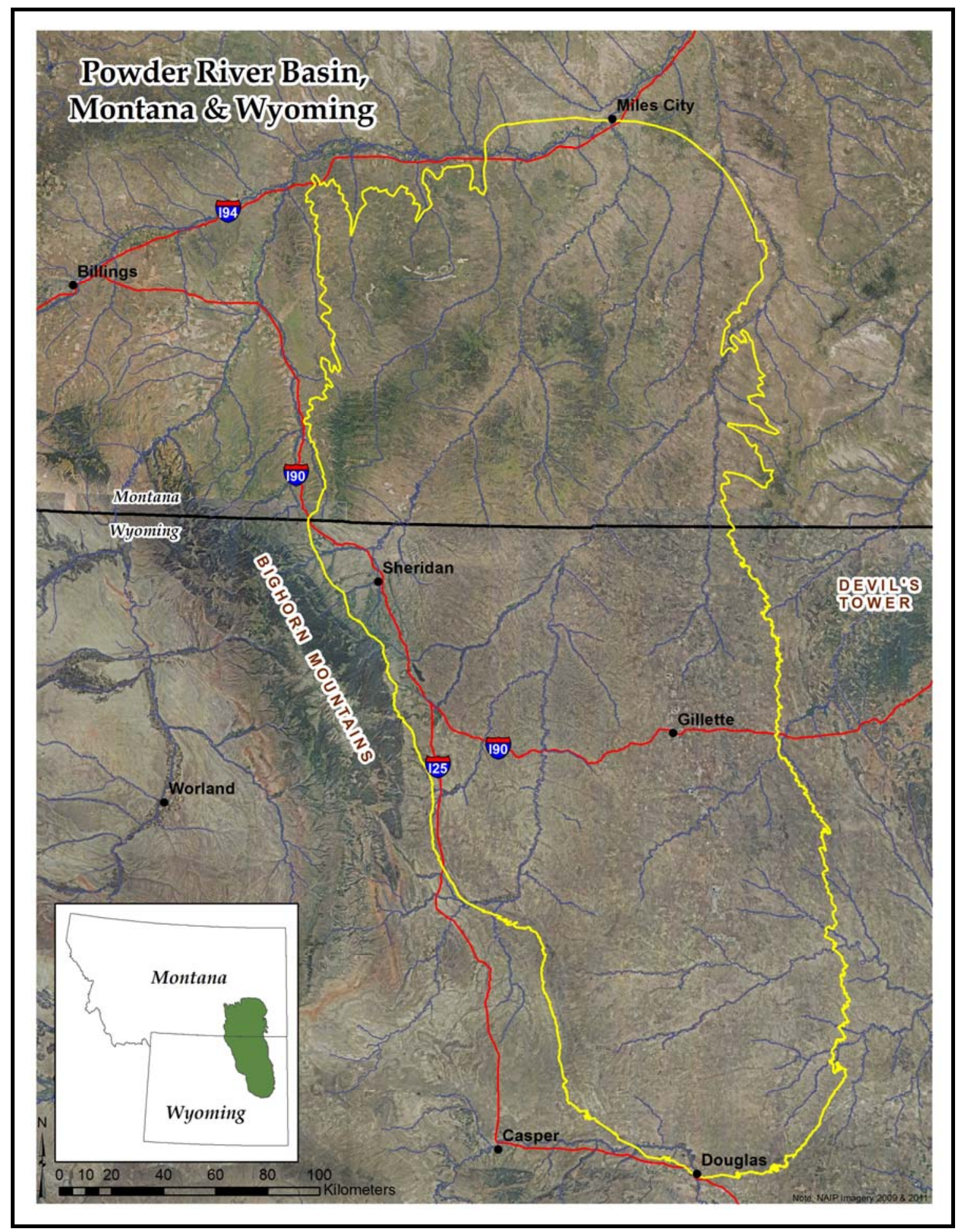

FIGURE 1: POWDER RIVER BASIN, MONTANA AND WYOMING 
The basin, with few reliable natural water resources in summer, cold and windy in winter, is a marginal environment for cultivation. There are just two cities in the PRB with more than 5,000 residents, Sheridan and Gillette. Land in the basin is divided among private owners (mostly ranchers), the State of Wyoming, and federal government lands administered by the Bureau of Land Management (BLM), and the United States Forest Service, creating a "checkerboard" of ownership categories across the PRB (Bureau of Land Management 2012) (Figure 2).

Ownership creates conflict in more ways than one. Wyoming and Montana both have large tracts of land that are split estates (or severed estates). This situation occurs when surface land and mineral rights are owned by separate entities (usually the federal government owns the mineral rights, and the surface land is owned privately). According to both federal and Wyoming state laws, mineral estates are dominant (i.e. the owner of the mineral rights has superior right of access across the surface above the minerals) (Fitzgerald 2009). In the case of the PRB, the federal government owns $63 \%$ of the subsurface mineral rights and can lease them to the highest bidder (Figure 3); approximately $65 \%$ of the surface over those rights is owned privately (Straube and Holland 2003: 2). This has created eruptive tensions within the various communities of the PRB, and multiple lawsuits have occurred contesting federal rights to energy development and mineral resource extraction. 


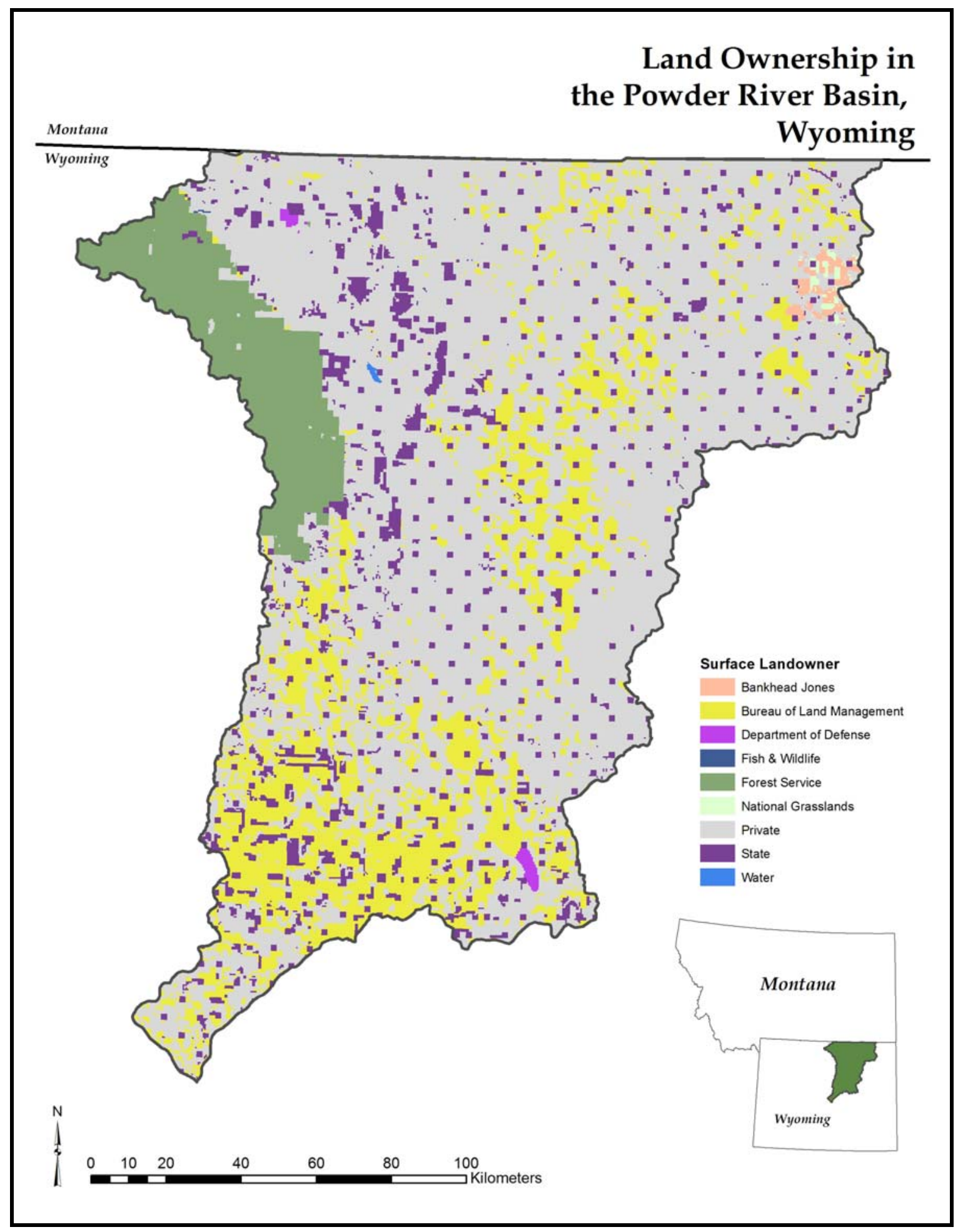

FIGURE 2: SURFACE AND MINERAL OWNERSHIP IN THE PRB 


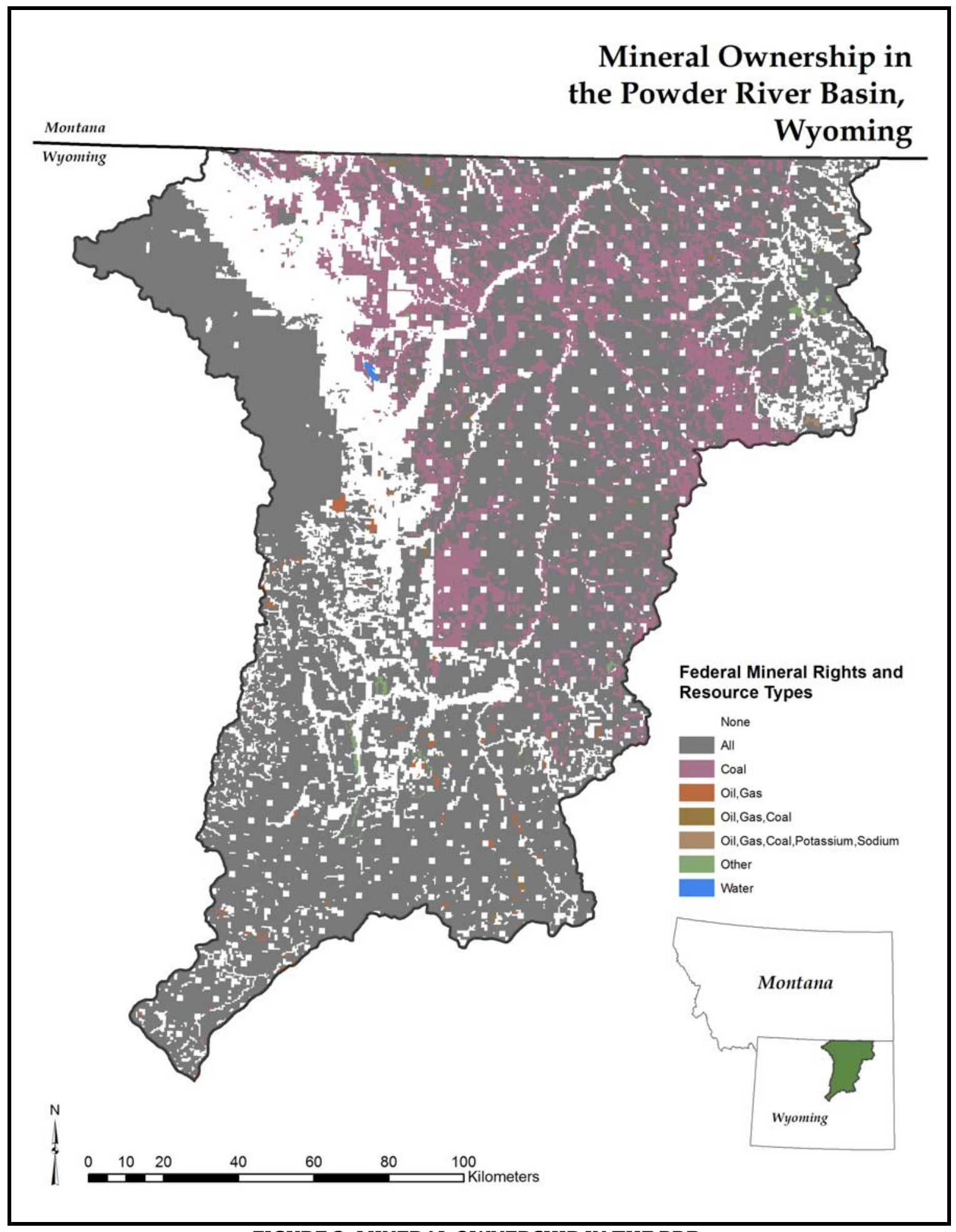

FIGURE 3: MINERAL OWNERSHIP IN THE PRB 
Energy production companies lease mineral rights in the PRB from federal or state agencies (such as the BLM or the State of Wyoming). The tensions surrounding split estates have become explosive in the PRB as intensive natural resource extraction has boomed in recent years. Coalbed methane extraction, natural gas extraction, and coal strip-mining all increased during the late 1990's and early 2000 's. The trend continues today, with an estimated 20,000 natural gas wells in the PRB in 2007 (Swindell 2007). Wyoming is currently the largest exporter of coal in the United States and home to some of the largest strip mines in the world. The infrastructure of a heavily developed energy field or strip mine consists of drill pads, well pads, strip mines, haul roads, access roads, railroads, water lines, gravel laydown yards, pipelines, transmission lines, mobile office trailers, parking lots and more. These activities severely disturb the ground surface - and any cultural resources found there.

Cultural resources are broadly defined to include artifacts, features, or landscapes that are significant to the cultural identity of a group of people. Precontact cultural resources are abundant in the basin. Hunter-gatherers inhabited the PRB beginning 12,000 to 15,000 years ago, and traces of their lifeways are evident on the surface throughout the PRB, most often found in the form of stone tools and other artifacts created from porcellanite - a mineral created when inclusions of silica, in clinker deposits, are subjected to heat and pressure. (While clinker deposits do occur in other regions, the dense outcroppings of clinker with porcellanite nodules are unique to the PRB). This useful tool-stone was quarried 
from clinker outcrops and represented a local, easily procurable commodity probably heavily exploited by mobile human groups throughout prehistory (Frison 1991). Clinker outcrops resist erosion, stand high in the landscape, and create ecoislands of resources in the relative desert of the PRB.

Porcellanite is thus a key component of prehistoric landuse in the Powder River Basin; for coal extraction companies, clinker deposits are useful surface indicators of subsurface coal. Coal companies use the deposits to identify the best site for the next strip mine or to expand a pre-existing one (Heffern et. al 2007). These two resources, carbon and cultural, co-exist near clinker deposits, increasing the likelihood of conflict between the destructive exploitation of mining and the protection required by federal law for important cultural sites.

Since the mineral rights are predominantly leased from federal (or state) agencies, occur on federal lands, or require federal permits, these activities (or undertakings) are subject to federal law; in particular, the National Historic Preservation Act (NHPA) and the National Environmental Policy Act (NEPA). Any undertaking on federal or state land, or benefiting from federal monies, requires compliance with NEPA and NHPA, both of which govern cultural resource management (CRM) (King 2008).

These laws identifying and documenting important cultural resources gave rise to the CRM industry, which functions as a compliance officer between the resource extraction company and federal regulations over cultural resources. CRM firms provide their clients with recommendations designed to minimize a project's 
adverse effects on cultural resources deemed eligible for listing to the National Register of Historic Places (NRHP). The extensive resource extraction occurring in the PRB requires intensive cultural resource management to comply with federal regulations. Clinker represents one feature of the PRB that signals both the likelihood of rich carbon resources and relics of early human occupation.

This study explores the current conditions of natural resource extraction in the PRB, the cultural resource management laws governing the relationship between resource extraction and cultural heritage, and the prehistory of the PRB. I then present a tool intended to aid cultural resource managers to predict the probable concentrations of cultural resources based on proximity to clinker deposits in combination with other variables. 


\section{Chapter 1: Mining in the Present}

Wyoming is home to a wealth of mineral resources, with clean-burning coal and coalbed methane in the Powder River Basin the most productive and exploited. The Wyodak coal seam located beneath the PRB is a low-sulfur, sub-bituminous coal seam averaging between 15 and 30 meters (50 and 100 feet) thick and stretching a distance of 65 kilometers (40 miles) (Swindell 2007). By comparison, eastern United States coal seams (such as those in Pennsylvania) are higher in sulfur content and are a-bituminous (Tewalt et. al 2000). Coal extraction in the PRB makes Wyoming the provider of a significant portion of the nation's mineral commodities; it is currently the largest producer of coal in the United States. In 2010, 17 active surface coal mines operated in the PRB; some of them are the largest open pit mines in the world. Ten are the highest producing coal mines in the United States; the Black Thunder Coal Mine near Gillette, Wyoming is the most productive and the largest scale coal mine (Bureau of Land Management (BLM) Wyoming 2010 Annual Report:3) (Figure 4)

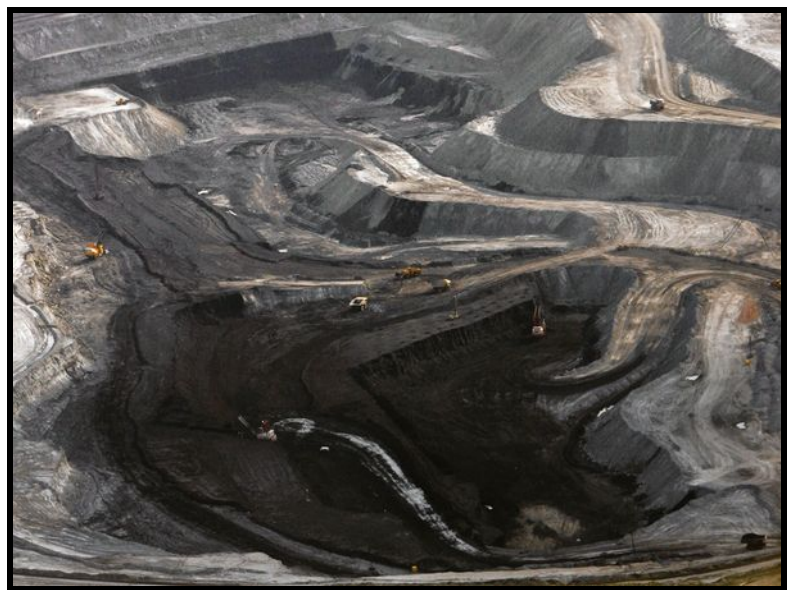

FIGURE 4: COAL MINE NORTH OF GILLETTE, WY (WWW.NATIONALGEOGRAPHIC.COM) 
More than one third of U.S. coal (42.3\% in 2008) - roughly 496 million tons in 2010 - comes from the Powder River Basin (Considine 2009:8). The BLM mineral leases in Wyoming also currently lead the United States in federal oil and gas production, producing 27.6 million barrels of oil and 1,639 billion cubic feet of natural gas per year (BLM Wyoming 2010 Annual Report: 3). This large-scale production has substantial consequences for the landscape of the PRB.

The strip mining process begins with removal of the large vegetation on the ground surface and then the removal of the overburden (topsoil) at the shallowest location above the subsurface coal. Then the innerburden (sediment between surface and coal) is removed in parallel strips to gain access to the coal deposit itself (Figure 5). The overburden and innerburden are placed in spoils piles and used as filler in locations where the coal has been removed, or used as recontouring fill at the close of the strip mining project (Huang et al. 2011).

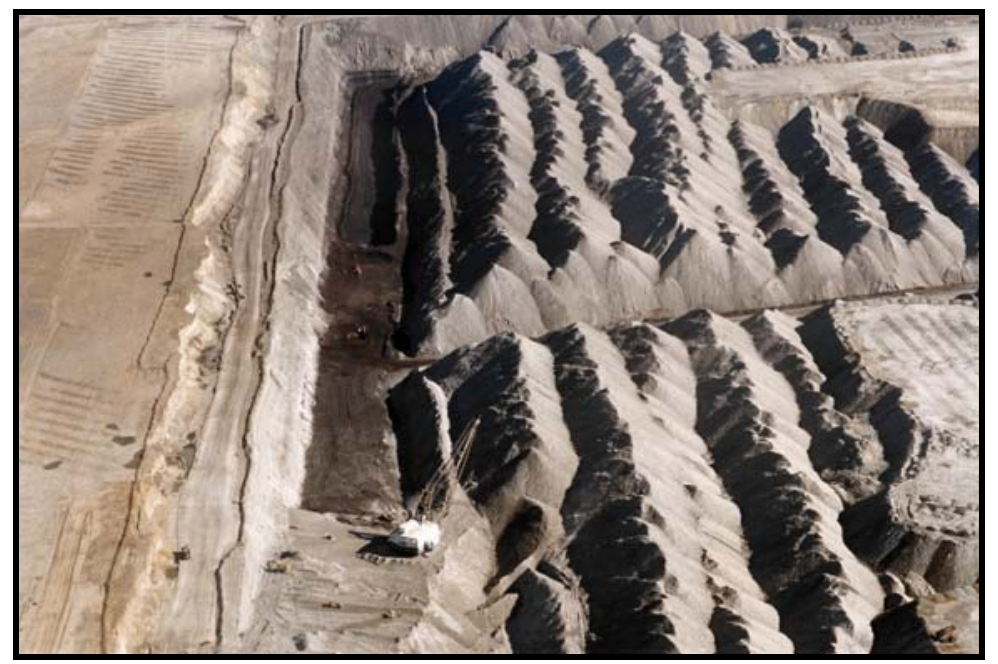

FIGURE 5: STRIP-MINING IN THE PRB (WWW.PLAINSJUSTICEBLOG.WORDPRESS.COM) 
In the PRB, finding coal is relatively easy, since specific indicators of the presence of coal can be seen on the surface in the form of clinker deposits (Figure 6). Because of this correlation between clinker and coal, clinker has been precisely and accurately mapped across Wyoming, North Dakota, and Montana. Clinker outcrops are found in the Upper Paleocene Tongue River member of the Fort Union Formation and in the Lower Eocene Wasatch Formation (Stracher 2007: 121). The Fort Union Formation is comprised of three members (the Tongue River, the Lebo, and the Tullock) deposited in a series of continental rock units as a result of a retreating interior seaway (Miller 1991: 465). Coal deposits are mainly located in the Lower Eocene Wasatch Formation, but can also be found in the Fort Union Formation (Heffern et al. 2007: 156).

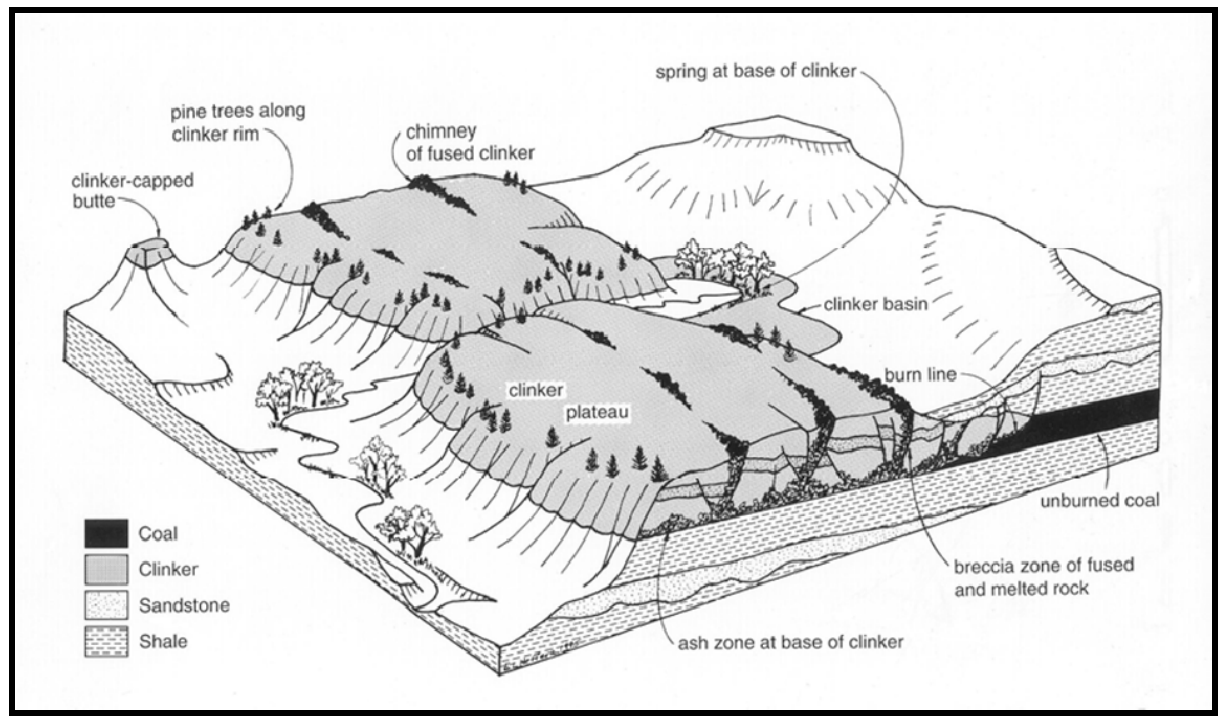

FIGURE 6: CLINKER TOPOGRAPHY (HEFFERN ET AL. 2007)

Clinker deposits are defined as baked, welded, or melted rocks formed by the natural burning of subsurface coal veins (Heffern et al. 2007). These underground coal fires occurred throughout the Pliocene and continue today. Clinker deposits, 
superheated from below, metamorphose into rocks that "clink" when tapped against one another. Pockets of silica-rich minerals within the clinker are superheated to such a degree that they form a partially glassy material referred to as porcellanite. Nodules of porcellanite occur only within clinker, and were put to use by early hunter-gatherers to create stone tools throughout the pre-contact era. 


\section{Chapter 2: Hunting and Gathering in the Past: The Early Occupation of the PRB}

Seasonal changes dominate life on the Plains. Animal behavior changes seasonally and had to be understood by Native Americans to ensure success in hunting. Wild plant foods - whether seeds, berries, fruits, leaves, roots, tubers, or blossoms - appear and disappear rapidly, and careful scheduling of group movement in response to their periods of availability was necessary. Late spring through early fall is a time of food abundance, easy travel and relative comfort. Late fall through early spring is a time of rapid and unpredictable changes in weather and the availability of food. Winter blizzards followed by prolonged period of subzero weather inhibited food procurement, and survival required some food storage (Frison 1998: 141).

Frison describes the life of native peoples occupying Plains environments such as the Powder River Basin before European contact. The Northern Great Plains is a challenging environment for humans. According to Frison and others, people living in the region from approximately 12,000 years BP to contact with European settlers were hunting and gathering across a wide territory, probably as small, extended family units. A group would follow a circuit through the Plains, from the mountains in the spring and summer to the lower flatlands and open plains in the fall and winter. Throughout time periods defined as Paleo-Indian $(11,200$ to 8,000 BP), Plains Archaic (8,000 to 2,000 BP) and Late Plains Prehistoric (2,000 BP to contact) in the Northern Great Plains, hunter-gatherers were hunting bison, antelope, and other large and small game, and gathering a variety of plant materials (Carlson 1998; Frison 1991).

The arrival of human groups to North America signals the beginning of the Paleo-Indian time period, evidenced by a solid archaeological record of human 
presence (although human groups potentially arrived much earlier than 11,200 years ago). During this period, hunter-gatherers in the Northern Great Plains were hunting big game (such megafauna as mammoths, mastodons, prehistoric camels, and giant bison) during a climatically stable period of cool, wet weather dominated by the glaciers to the north (Carlson 1998; Burroughs 2005). During this period, diet, technology and settlement patterns maintain a high level of continuity through the archaeological record, with only small shifts in projectile point technology over the course of the Paleo-Indian era (Wood 1998). Lithic technology employed by the Paleo-Indian hunters is best known by the large, fluted points such as the wellknown Clovis, Goshen, and Folsom complexes. Although the archaeological record of Paleo-Indian sites is limited in comparison to other time periods, the evidence suggests that these groups were using a broad spectrum of food resources, but were at least seasonally specializing in big-game hunting evidenced by large communal bison kill sites (Hofman and Graham 1998). These hunting groups ranged widely in the region, not only for hunting but most likely also conducting trading forays and broader social activities such as marriages, rites of passage and other ceremonies (Carlson 1998; Hofman and Graham 1998).

About 8,000 years ago, the climate became hot, dry, and windy as the glacial front retreated and aridity increased in the Northern Great Plains (Burroughs 2005). It was during this time (referred to as the Hypsithermal drought), after widespread extinction of the megafauna hunted during the Paleo-Indian period, the Plains Archaic period begins, ushering in an era characterized by continued reliance 
on bison hunting on the open plains, as well as other foothill-mountain resources. This period signals the burgeoning use of manos and metates (grinding tools) for use in seed and plant food processing, which became common throughout this and later periods (Frison 1998). Lithic artifacts from this period include scrapers, choppers and projectile points known for the distinctive side-notch such as Pryor Stemmed (Early Plains Archaic), the McKean complex (Middle Plains Archaic), Pelican Lake, Besant, and Avonlea complexes (Late Plains Archaic). Groups during this period seem more restricted to local territories and very little evidence suggesting longrange movement or trade can be found in the archaeological record. Many of the locations of archaeological sites dating to this period are found in caves and rockshelters, apparently used extensively by human groups during yearly rounds. While shallowly excavated pit-houses are in evidence in other regions of the Northern Great Plains, structures in the Powder River Basin are predominantly caves, rockshelters, and tipi rings (Frison 1998).

The evidence suggests that these groups were focused on opportunistic hunting and gathering in a variety of ecological zones, encountered during their yearly round. The archaeological record also suggests that during this time, foodcaching became a fairly common practice in the foothill-mountain slope zones (Frison 1998). Seasonality determined both the resources to be hunted or gathered as well as the length of time a group could remain in one place (Carlson 1998). Natural resources near camps became depleted over time, depending on the number of people in a group, the weather patterns of any particular year, and a 
variety of other factors. The sites most often returned to would ideally provide good shelter and access to plants, lithic sources and water. In the Powder River Basin, areas near clinker deposits would have been ideal for long term or returning camp locations because of access to water as well as access to porcellanite outcrops and nearby plant resources that prefer clinker soils. Strategies employed by these groups to acquire resources were closely related to the distribution and density of natural resources across the landscape (Kelly 1995; Carlson 1998). Groups would have returned to camps that provided many resources again and again over the seasons or years. Mobility was a critical aspect of hunter-gatherer life in an environment where islands of resources punctuate an otherwise stark landscape. Archaic lifeways in the Great Plains continued with relatively stability until the arrival of the European settlers to North America and their subsequent expansion to the west (Carlson 1998).

Abrupt changes occur in Northern Great Plains prehistory after approximately AD 1400, referred to as the Late Plains Prehistoric period (Carlson 1998). A climatic shift resulting in severe droughts across the region coincided with the European explorer Francisco Vasquez de Coronado's arrival in the Great Plains in 1541. Prior to the arrival of Europeans, the hunter-gatherer lifeway was conducted on foot and with the help of pack dogs (Frison 1998). After the arrival of the horse, the mobility and hunting practices of Native Americans shifted dramatically, and by the $18^{\text {th }}$ century the Plains groups were fully dependent on the horse (Carlson 1998). Both the horse and newly acquired firearm power allowed 
more efficient hunting, the ability to own more personal possessions, and became a new symbol of wealth and trade. On the Northern Great Plains specifically, large, military, nomadic, big-game hunting cultures emerged, known for their annual bison hunts and Sun Dance ceremonies (Carlson 1998). These cultures were in full evidence by AD 1770 and lasted nearly a century before collapse from disease, warfare and pressure from incoming settlers (Carlson 1998). High Plains equestrian nomadic groups included the Cheyenne, the Arapahos/Gros Ventre and the Crow who inhabited the Powder River Basin (Hanson 1998). Although the ethnohistorical data is common and rich with detail, the archaeological data from this period is difficult to assign to a particular Native American tribal group (Hanson 1998). The end of the Late Plains Prehistoric period ended rather abruptly after the treaties of Medicine Lodge in 1867 and Fort Laramie in 1868, after which the nomadic groups of Native Americans were placed on reservations (Carlson 1998).

As the climatic and environmental conditions changed over the Holocene, hunter-gatherer bands adjusted their methods of procuring resources, as revealed by changes in activity areas, structures and storage units, lithic technology, and artifact assemblages. In the Early Plains Archaic, the burgeoning use of plant foods and seeds altered gathering patterns during the yearly round, and in the Late Plains Prehistoric period, the introduction of the horse and firearms yet again fundamentally changed hunting methods. Over time, climatic conditions shaped the distribution of the natural resources in the PRB, causing shifts in movement and in locations of camps and residences (Kelly 1995; Frison 1991). Of course, one type of 
resource site was rooted in geology. Clinker deposits and the tools created from porcellanite remained critical for the entire period of human occupation.

Lithic resources are stones used to create tools or for use in ceremonial contexts. These stones are procured in various ways, from finding cobbles on the surface to deliberate quarrying (Miller 1991: 449). One of the most common materials located at archaeological sites in the PRB is porcellanite, associated with clinker deposits (Frison 1991: 158-160). It has been established through archaeological investigation that some of the outcrops of clinker deposits served as quarries for prehistoric craftsmen. "Porcellanite was the dominant lithic materials used by prehistoric peoples...the stone tools produced from the porcellanite acquired from these locations were essential for the killing and processing of game, the manufacturing of wood and bone products, the manufacturing of clothing, etc." (Wagers 2006). Groups would probably have known the locations of quarries and resource hotspots throughout the landscape, and clinker deposits serve as focal locations in landscape use patterns (Frison 1991: 13; Wagers 2006).

Mapping and characterizing the distribution of porcellanite is the first step in studying prehistoric lithic procurement strategies in the PRB. There are fundamental reasons why the study of stone is of such importance in studying prehistoric peoples: lithic sources are more predictably located, they are rarely fully exhausted, and they are available throughout the seasons (Thacker 2006).

Archaeological materials represent the record of prehistoric lifeways on the Northern Great Plains, and provide archaeologists with important data. This data 
can help answer broad questions about how hunter-gatherers lived in the Plains across space and through time. The protection of these data sources (archaeological sites) which can shed light on prehistoric hunter-gatherers has been mandated by multiple federal laws throughout the 20th century. 


\section{Chapter 3: Cultural Resource Management Law}

Cultural resources are broadly defined as "cultural uses of the natural environment, community values, religious practices, historical documents, spiritual places, historic resources, archaeological resources, Native American cultural items, and historical objects" (King 1998: 7). Fowler (1982) defines cultural resources as "physical features, both natural and manmade, associated with human activity... including sites, structures, and objects possessing significance, either individually or as groupings, in history, architecture, archaeology, or human cultural development... cultural resources are unique and nonrenewable" (1). Lipe (1984) defines cultural resources in terms of landscape, by stating "because humans generally modify the landscapes in which they live, and because they attach names, myths and affective value to features of the territory they inhabit, the landscapes of past cultures may also qualify as cultural resources" (1). Beginning in the early $20^{\text {th }}$ century, the United States government took an interest in safeguarding such cultural resources through an evolving body of law and policy. Resource extraction and energy development in the Powder River Basin are governed by these laws and a profession, 'cultural resource management', has developed in response. The profession has developed to mediate the assessment and protection of artifacts of past peoples. 
This body of laws developed over the last century defines the methods and obligations of cultural resource managers and agencies responsible for protecting and preserving cultural resources. Key among these are the following :

- The Antiquities Act of $\mathbf{1 9 0 6}$ banned vandalism and theft for the first time on publicly owned lands.

- The Historic Sites Act of 1935 declared that objects of national significance exist, and must be protected by the National Park Service.

- The National Historic Preservation Act (NHPA) of 1966 created the institutions charged with preserving and protecting cultural resources.

- The National Environmental Policy Act (NEPA) of 1969 created an umbrella law protecting cultural and natural resources as a matter of public policy.

- Under Executive Order 11593 issued in 1971, President Nixon required agencies to inventory cultural resources under their jurisdiction.

- More recently, the Archaeological Resources Protection Act (ARPA) of 1979 provided stiff penalties for theft, vandalism, and damage to cultural resources to reinforce the intent of the Antiquities Act.

These federal actions define the legal relationship between natural resource extraction and the preservation of cultural resources in the PRB. The most significant of these laws, in terms of cultural resource management, is the NHPA, which establishes procedural requirements, defines key terms, and designates the oversight agencies charged with avoiding or minimizing adverse effects to important cultural properties. The NHPA was implemented to "encourage the preservation and protection of America's historic and cultural resources" and has emerged as "the cornerstone of federal historic and cultural preservation policy" (Stern and Slade 1995: 136). This law created a number of institutions that are central to CRM, including the National Register of Historic Places, the Advisory 
Council on Historic Preservation, the State Liaison Officers (now the SHPO), and the Office of Archaeology and Historic Preservation (OAHP) (King 2008: 15).

The NHPA directly influenced the formation and practice of CRM in two ways. First, the law required early consideration of cultural resources in the planning and operation of federal projects. Second, the law's requirements crafted the industry itself, including the employment of professional archaeologists in governmental positions, private subcontracting firms, and in academia (McManamon 2000: 47). The basic legal structure and operating mechanisms of the NHPA control the conduct of cultural resource managers and the Federal historic preservation program (Fowler 1982: 8).

The "Section 106" process, as it is known, was issued as a formal regulation under the NHPA in 1979 (King 2008; 36 CFR 800). Similar to NEPA's categorical exclusion, the Section 106 process first filters out development projects that do not require further review under NHPA by having the Federal agency ask if the project meets the definition of a federal "undertaking," and, if it does, asking whether it is the type of project that has the potential to affect a cultural resource site eligible for the National Register.

Projects determined not to be undertakings, and projects determined to have no potential to affect significant cultural resources are approved by the Federal agency. These findings satisfy the Section 106 requirement to consider effects, and do not require external party review. This is the initial step in the Section 106 
cultural resources clearance process; based on the decision reached by the Federal agency, it also may be the last (King 2008).

A project considered an "undertaking" under the definition of the NHPA is subject to the Section 106 review process. The first step defines the Area of Potential Effect (APE) by assessing direct physical effects (ground disturbance, for example) together with visual effects, auditory effects, sociocultural effects, effects on culturally significant natural resources, and indirect effects (like erosion or public use) (King 2008: 65).

Section 106 requires the agency to make a reasonable, good faith effort to identify historic properties that might be affected by the project. Acquiring information about the APE and determining potential effects on different types of cultural resources is the second step in the Section 106 process. Cultural resource specialists (most commonly archaeologists) review the literature to determine where archaeological surveys have been conducted, whether known historic properties are nearby, and what their National Register eligibility status is (King 2008: 67). Cultural resource specialists also conduct archaeological field surveys, with survey standards defined by each state or region's SHPO, to re-evaluate known resources within the APE or discover previously unrecorded archaeological sites. If any historic properties have been identified, the cultural resource specialist will determine whether those historic properties are eligible for listing to the NRHP before effects may be evaluated (36 CFR 800). 
To decide the eligibility of a historic property, cultural resource managers apply the "Criteria of Eligibility" defined in Federal regulations at 36 CFR 60.4 (Title 36, Part 60.4 of the Code of Federal Regulations). Properties less than 50 years old, unless they are exceptionally significant, are not eligible for listing in the NRHP. There are four categories under which a historic property can be deemed eligible for listing in the NRHP, with the added caveat that the property also must maintain integrity of "location, design, setting, materials, workmanship, feeling and association" (King 2008: 75). These criteria are defined as follows. An eligible property must be:

A. associated with events that have made a significant contribution to the broad patterns of our history; or

B. associated with the lives of persons significant in our past; or

C. embody the distinctive characteristics of a type, period, or method of construction, or that represent the work of a master, or that possess high artistic values, or that represent a significant and distinguishable entity whose components may lack individual distinction; or

D. have yielded, or may be likely to yield, information important to history or prehistory (36CFR800).

An important aspect of Section 106 is that a property deemed eligible for listing in the National Register is afforded the same protection against potential effects as if it actually were listed in the NRHP (Hardesty and Little 2000:6). It is also important to note that being listed as eligible for the NRHP does not always require physical preservation of the property. Mitigation of effects might only require documentation and photographs, compensation to various parties, or some type of commemoration. Once eligibility has been established, the next step in the Section 
106 process is to determine the type of effect (non-adverse or adverse) the undertaking may have on the property.

If the undertaking will have an effect as defined under NHPA, then the "Criteria of Adverse Effect" identified at 36CFR800.5 are used to determine whether the effect will, in fact, be adverse. If the effect is not adverse, then the Federal agency sends this finding for review and comments to the SHPO, ACHP, Tribes, and other "interested parties" for a 30-day period (36 CFR 800).

If the undertaking is determined to have an adverse affect on historic properties, defined as "diminishing the integrity of the aspects of the property that make it eligible to the NRHP" (King 2008:103), then additional consultation is required to find ways to avoid or minimize that effect.

Most often, mitigation options are developed in consultation with Native American tribes whose lands are affected, Native American or Native Hawaiian organizations that may attach cultural or religious meaning to the site, concerned citizens, or local governments with jurisdiction over the property. This process is legally concluded with a Memorandum of Agreement (MOA), which must be signed by specific parties in order to bind the undertaking to the agreements reached between the consulting parties on how to mitigate the adverse effects of the project on historic properties (36 CFR 800).

In some cases, alternatives to the standard Section 106 process are needed, as for example in the case of projects that extend over long periods of time, or involve multiple agencies, or cover multiple states. One of the standard alternatives 
is the Programmatic Agreement (PA), which is forged between the ACHP, the responsible agency, appropriate SHPO(s), and other concerned parties. The result of this discussion is a definition of how the project is to be conducted and detailed instructions regarding requirements for the assessment and preservation of cultural resources (King 2008: 141). Once a PA is in place, the stipulations of the PA substitute for the standard Section 106 regulations.

Typically, the Section 106 process is conducted for federal agencies or private industry (like coal companies) by cultural resource managers or specialists, who make recommendations to the coal companies to make sure that they remain in compliance with federal law. A coal company hires a CRM firm to conduct the Section 106 review for a given project. The CRM firm employs archaeologists, and deploys a team to survey the project area on foot, reporting any cultural resources located there. If no cultural resources are located and none has been found there in the past, the CRM firm submits a report to the SHPO concluding that there is no potential to cause effect to a historic property. If cultural resources are found, the cultural resource specialist evaluates the artifacts, determines the site's eligibility to the NRHP, and prepares a document to submit to the SHPO for review. If the site is determined not eligible, no further action is required. If the site is determined eligible, consultation and mitigation are required by federal law. These steps can be pursued in a number of ways, usually resulting in a formal legally binding agreement between the coal company, the CRM firm and the SHPO. Once mitigation 
and consultation are concluded, the Section 106 process is complete for the project and they are given clearance to proceed.

The complex Section 106 process slows energy development and provides the incentive for a statistical model that facilitates the identification of likely locations of cultural resources, some of which may be eligible to the National Register and require expensive mitigation efforts. My efforts to develop a useful, efficient tool are described in the following chapter. 


\section{Chapter 4: Case Demonstration - A Predictive Model for Delineating the Probable Concentrations of Cultural Resources}

Because of the co-location of coal extraction and cultural resources, a model that defines the relationship between cultural resources and clinker deposits would help to simplify the process of identifying coal development areas both suitable for mining and legal under the law. Knowing how cultural resources are related to clinker deposits allows cultural resource managers to make informed decisions about recommendations to their clients regarding project locations, helps coal companies maintain better compliance with cultural resources laws, and avoids the need for mitigative measures for adverse impacts to cultural resources.

Such a model demands understanding of both the way prehistoric peoples used the Powder River Basin, and the expression on the land of high-value coal deposits. The interpretation of prehistoric mobility and resource use in the PRB necessary to developing this modeling tool, requires a model of hunter-gatherer behavior in the PRB. Predictive models of archaeological activity areas associated with natural resource use have been successful at predicting a high percentage of archaeological site locations (Banks et al. 2009; Rua 2009; Taliaferro et al. 2009; Arakawa and Nicholson 2008; Howey 2007; Brewster et al. 2003; Krist and Brown 1994). Table 1 (below) offers a sample of similar archaeological predictive models, the variables used, and the types of analysis conducted. These models offered insight regarding variables and methodologies required to predictively model the locations of archaeological sites. These predictive models have been helpful in 
establishing time frames of occupation as well as trends in the use of short term

camps, camps used seasonally, and those used over much longer spans of time.

Predictive models can aid in determining the important resources that people used

and how use of those resources changed through time.

TABLE 1: SAMPLE OF LITERATURE ON PREDICTIVE MODELING AND ARCHAEOLOGY

\begin{tabular}{|c|c|c|c|}
\hline $\begin{array}{l}\text { Author/ } \\
\text { Year }\end{array}$ & Title & Variables & Types of Analysis \\
\hline $\begin{array}{l}\text { Kvamme } \\
\text { (1982) }\end{array}$ & $\begin{array}{l}\text { Methods for Analyzing and } \\
\text { Understanding Hunter-Gatherer } \\
\text { Site Location as a Function of } \\
\text { Environmental Variation }\end{array}$ & $\begin{array}{l}\text { Elevation, Drainages, } \\
\text { Average slope (and then } \\
\text { combinations of these } \\
\text { three base variables) }\end{array}$ & $\begin{array}{l}\text { Stepwise multiple } \\
\text { linear regression }\end{array}$ \\
\hline $\begin{array}{l}\text { Brandt et } \\
\text { al. (1992) }\end{array}$ & $\begin{array}{l}\text { An Experiment in } \\
\text { Archaeological Site Location: } \\
\text { Modeling in the Netherlands } \\
\text { using GIS techniques }\end{array}$ & $\begin{array}{l}\text { Soils texture, } \\
\text { Geomorphology, } \\
\text { Ecological border } \\
\text { distance, Distance to } \\
\text { water }\end{array}$ & $\begin{array}{l}\text { Weighted map-layer } \\
\text { approach }\end{array}$ \\
\hline $\begin{array}{l}\text { Krist and } \\
\text { Brown } \\
(1994)\end{array}$ & $\begin{array}{l}\text { GIS modeling of Paleo-Indian } \\
\text { Period Caribou Migrations and } \\
\text { Viewsheds in Northeastern } \\
\text { Lower Michigan }\end{array}$ & $\begin{array}{l}\text { Waterbodies, } \\
\text { Topographic contours, } \\
\text { archaeological site } \\
\text { locations, hydrography, } \\
\text { elevation, slope angle, } \\
\text { slope aspect }\end{array}$ & $\begin{array}{l}\text { Weighted cost } \\
\text { surface, Least cost } \\
\text { path, Viewshed } \\
\text { analysis }\end{array}$ \\
\hline $\begin{array}{l}\text { Duncan } \\
\text { and } \\
\text { Beckman } \\
(2000)\end{array}$ & $\begin{array}{l}\text { The Application of GIS } \\
\text { Predictive Site Location Models } \\
\text { within Pennsylvania and West } \\
\text { Virginia }\end{array}$ & $\begin{array}{l}\text { Prehistoric site locations, } \\
\text { Historic Indian trails, } \\
\text { roads/disturbance } \\
\text { factors, hydrologic } \\
\text { features, soils, elevation }\end{array}$ & Logistic regression \\
\hline $\begin{array}{l}\text { Warren } \\
\text { and Asch } \\
(2000)\end{array}$ & $\begin{array}{l}\text { A Predictive Model of } \\
\text { Archaeological Site Location in } \\
\text { the Eastern Prairie Peninsula }\end{array}$ & $\begin{array}{l}\text { Elevation, streams, soils, } \\
\text { vegetation, archaeological } \\
\text { sites, survey area }\end{array}$ & Logistic regression \\
\hline $\begin{array}{l}\text { Bevan and } \\
\text { Conolly } \\
(2004)\end{array}$ & $\begin{array}{l}\text { GIS, Archaeological Survey, and } \\
\text { Landscape Archaeology on the } \\
\text { Island of Kythera, Greece }\end{array}$ & $\begin{array}{l}\text { Contours, cultural } \\
\text { topography (current } \\
\text { roadwas, buildings, etc.), } \\
\text { bedrock geology, } \\
\text { elevation, site location, } \\
\text { ceramic distribution, } \\
\text { terrain ruggedness }\end{array}$ & $\begin{array}{l}\text { Cumulative } \\
\text { frequency, dot } \\
\text { density }\end{array}$ \\
\hline $\begin{array}{l}\text { Espa et a. } \\
(2006)\end{array}$ & $\begin{array}{l}\text { GIS Based Models and } \\
\text { Estimation Methods for the } \\
\text { Probability of Archaeological } \\
\text { Site Location }\end{array}$ & $\begin{array}{l}\text { Lithologies (stone tool } \\
\text { sources), land use, } \\
\text { elevation, slope, } \\
\text { hydrography (distance to } \\
\text { water) }\end{array}$ & $\begin{array}{l}\text { Discriminant } \\
\text { analysis, logistic } \\
\text { regression and } \\
\text { classification and } \\
\text { regression trees }\end{array}$ \\
\hline
\end{tabular}




\begin{tabular}{|l|l|l|l|}
\hline $\begin{array}{l}\text { Author/ } \\
\text { Year }\end{array}$ & Title & Variables & Types of Analysis \\
\hline Howey & $\begin{array}{l}\text { Using Multi-Criteria Cost } \\
\text { Surface Analysis to Explore Past } \\
\text { Regional Landscapes: A Case } \\
\text { Study of Ritual Activity and } \\
\text { Social Interaction in Michigan, } \\
\text { AD 1200 - 1600 }\end{array}$ & $\begin{array}{l}\text { Waterways, Slope and } \\
\text { Historic vegetation } \\
\text { landcover }\end{array}$ & $\begin{array}{l}\text { Cost Surface } \\
\text { Analysis }\end{array}$ \\
\hline
\end{tabular}

The use of GIS-based predictive models can inform searches for prehistoric hunter-gatherer activity or occupation areas in zones that have not yet been traversed (Verhagen 2007; Conolly and Lake 2006; Mehrer and Wescott 2006; Wheatley and Gillings 2002; Aldenderfer and Maschner 1996). There are various ways to use GIS data for practical applications in geographic and archaeological analyses. In addition to predictive modeling, some of these techniques include agent-based modeling, viewshed analysis and intervisibility studies, game movement and migration, surface models, cost-surface and least-cost path analyses, intra-site and inter-site artifact distributions, etc. (see for example, Arakawa and Nicholson 2008; Brewster et. al 2003; Llobera 2007; McCoy and Ladefoged 2009; Rua 2009). However, predictive modeling using cost surface estimates in the PRB is reasonable given the landscape variables (such as clinker deposits) and scale of the basin, coupled with high human mobility during the pre-contact period.

Creating a successful predictive model for the PRB has the potential to create future guidelines for extraction companies and cultural resource managers, and also foster research questions based on the outcome of the study. In the case of predictive modeling, two styles of modeling are recognized, although they are 
commonly viewed as mutually inclusive - correlative (or theory-driven) and explanatory (or data-driven) (Verhagen 2007: 13; Wheatley and Gillings 2002: 166).

In a correlative approach, a hypothesis is formed and then tested by "predicting" the location of archaeological sites based on an independent variable, and then testing the model with known locations of archaeological sites (Wheatley and Gillings 2002: 166). "Explanatory or deductive models appear to be generally concerned with systemic context, but from a cultural resource management standpoint the goal clearly seems to be the modeling of the archaeological context" (Mehrer and Wescott 2006:13).

In a data-driven approach, empirical data that is gathered can be used to formulate a correlation between archaeological site location and an independent variable, and this correlation can be extrapolated to a larger area (Verhagen 2007: 14). The main issues with a data-driven approach to predictive modeling lie in the fact that datasets are often incomplete or inaccurate; there is a biased selection of parameters that rely heavily on the environment with no cultural factors; and the changing nature of the landscape is not reflected in the model (Verhagen 2007: 17).

In this thesis, I demonstrate the construction, validation and application of a data-driven predictive model that employs a logistic regression technique. Models of the environment require specific inputs that are based on empirically-derived data to predict the presence/absence of a site, site class, densities of artifacts, patterned artifact distributions, site significance, or site probability (Wheatley and Gillings 2002: 167; Kohler and Parker 1986: 400). Logistic regression models have been 
demonstrated to be effective in building such environmental models (Kvamme 1982; Duncan and Beckman 2000; Warren and Asch 2000; Espa et al. 2006). A logistic regression model depicts the interactions between categorical dependent variables and independent variables through a mathematic equation in which coefficients are estimated through an optimization mechanism such as maximum likelihood estimation. The choice of variables to use in the predictive model was informed by past predictive models of archaeological site distributions coupled with the local PRB variable of clinker deposits. The model demonstrated here is based on a data-driven approach, and is presented with both limitations and potential future research paths.

In this case study, by creating a basic predictive model for site locations in relation to a specific geological marker as well as other independent variables, I demonstrate the potential usefulness of this tool and analysis for cultural resource management in the PRB. The independent variables of the model include slope, water as a barrier, terrain ruggedness, distance to water, distance to clinker deposits, and a combination of both distances (i.e. the best location to access both resources). In general, A) people do not live or camp on steep, rugged slopes; B) people require water for survival; C) people choose to camp near sets of resources, and D) people need stone to make tools. For this model, I isolated areas near water and on relatively flat land that are close to clinker deposits. Once these prime locations were located, I compared those areas to known sites locations to validate the model. 


\section{STUDY AREA}

The study area is comprised of the Upper, Middle, and Lower Powder River sub-basins of the Powder River Basin, and is bounded by the archaeological inventory area boundaries from the Wyoming SHPO database (Figure 7). Only areas formally surveyed by professional archaeologists using state survey standards were included in the study area (Figure 8).

Although the Powder River Basin is located in both Montana and Wyoming, the study area was limited to Wyoming because of data constraints. The Powder River Basin archaeological data in Wyoming was digitized recently during a research study to develop soil models. This digitized data includes approximately $98 \%$ of the archaeological resources documented in the Powder River Basin (personal communication, Mary Hopkins, Wyoming SHPO, 04/29/2010). Although many inventories have been conducted in the Wyoming portion of the Powder River Basin, the Middle Powder River sub-basin has the largest semi-contiguous areas that have been previously surveyed, and thus presented the most opportune place to create a predictive model. 


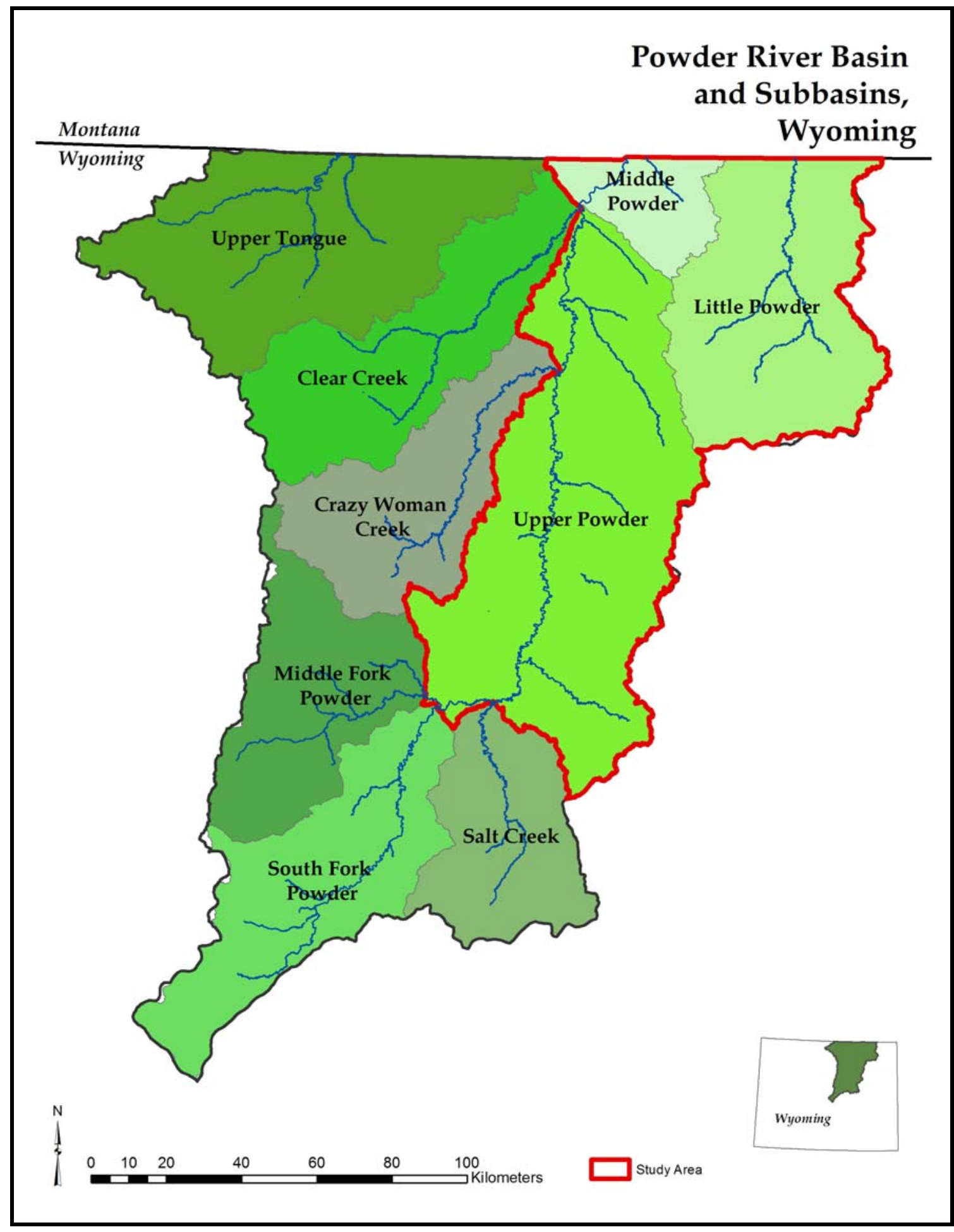

FIGURE 7: POWDER RIVER BASINS AND SUB-BASINS 


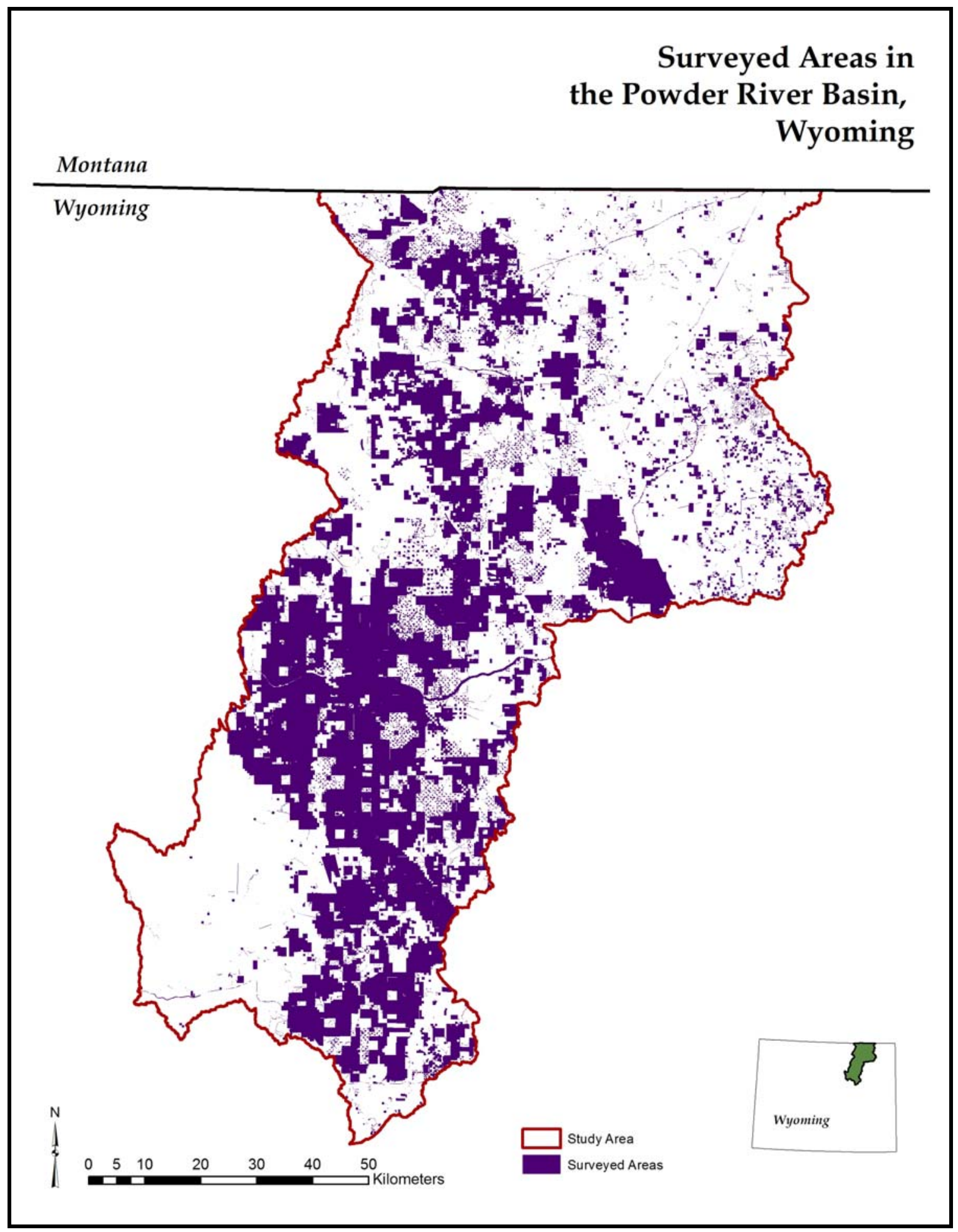

FIGURE 8: SURVEYED AREAS WITHIN THE STUDY AREA 
MODEL

Logistic regression can be based on a categorical dependent variable, the simplest of which is a binary variable, such as presence or absence. Logistic regression analysis attempts to describe the relationship of dependent and independent variables using a non-linear logarithmic equation. The results of this analysis can describe relationships of different variables and offer a percentage of the dependent variable that can be predicted by the independent variables (Rogerson 2006). In this research, the goal was to determine the statistical relationship between archaeological site locations and various independent variables (slope, distance to water, elevation and terrain ruggedness). An added goal was to determine the percentage of sites that can be statistically predicted by the location of clinker deposits. Binary logistic regression analyses are used to evaluate the effectiveness of the predictive model in determining the relationship between archaeological sites and resource areas (dependent and independent variables).

\section{DATA SOURCES}

The datasets used in this analysis were acquired from a variety of locations. The Wyoming SHPO provided access to the Wyoming Cultural Resources Information System (WYCRIS) database, which houses the datasets of archaeological sites and formally surveyed areas. From the United States Geological Survey (USGS), I acquired a 30-meter resolution Digital Elevation Model (DEM), from which I calculated elevation, slope, and the Terrain Ruggedness Index (TRI). The USGS also provided the clinker geological strata dataset. A dataset containing 
watershed basins, subbasins, catchments and river data was downloaded from the National Hydrography Dataset (NHD).

VARIABLES

SLOPE

Slope was chosen as an important variable because it impacts the way that humans traverse the landscape and is commonly used in models of archaeological site location (Kvamme 1982; Krist and Brown 1994; Espa et al. 2006; Howey 2007). In general, humans prefer not to set up long term campsites or habitation zones in areas of steep slopes, but rather would concentrate their living and activity areas nearer to water and on flatter ground that provides a comfortable occupation area. Camping on steep slopes also requires the traversal of those slopes many times a day during hunting and gathering activities, such as berry picking and water hauling as well as butchering or vegetable processing. The only times in prehistory that difficult to traverse areas are regularly inhabited has been during intense conflict, with neighbors or nearby raiders.

How people experience slope is difficult to quantify. Howey (2007:1836) states "since the relationship between slope and the effort to traverse it is not linear, with relative cost increasing steeply with slope angle...to create a relative non-linear slope cost grid, the tangent of the slope was taken and divided by the tangent of one degree...this more accurately reflects the way someone on foot experiences slope" (see Figure 9). I used the same methodology in my calculation of slope for the purposes of this research. 


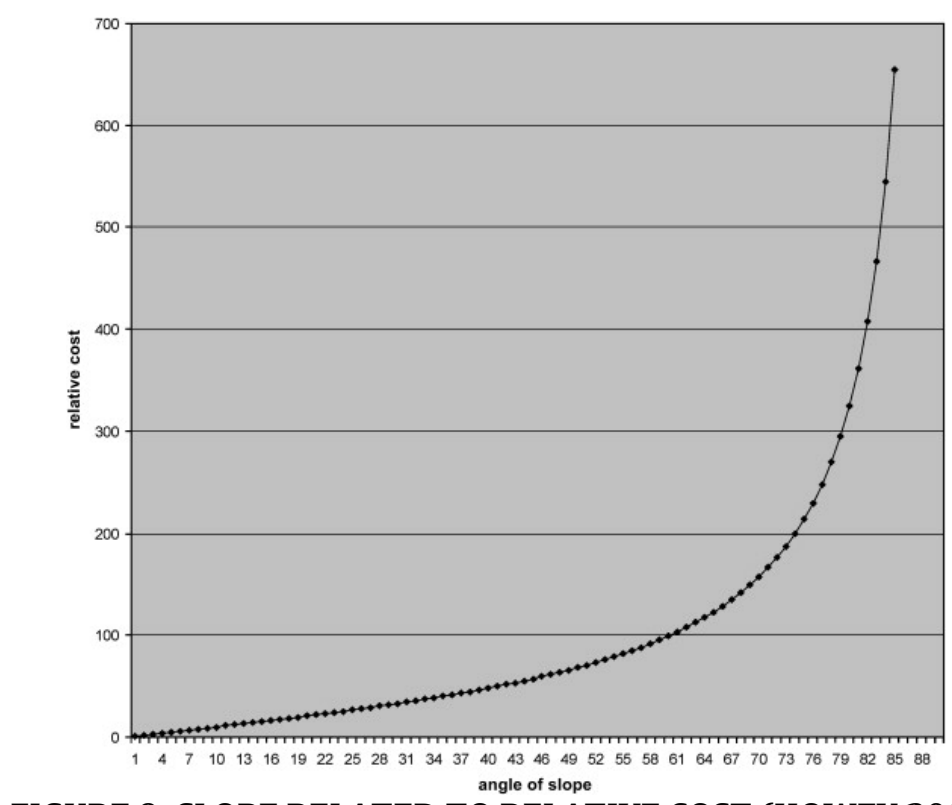

FIGURE 9: SLOPE RELATED TO RELATIVE COST (HOWEY 2007)

\section{DISTANCE TO WATER}

Throughout time, sources of water for hydration, riparian flora and fauna, and for transportation have been a constant factor in human use of the landscape (Brandt et al. 1992; Krist and Brown 1994; Duncan and Beckman 2000; Warren and Asch 2000; Espa et al. 2006). Prehistorically in the PRB, the aridness of the surrounding landscape left few places to inhabit year-round that would provide a permanent water source. The three rivers that run through the study area, the Upper, Middle and Lower Powder Rivers, are the major sources of water in the area. Water sources are also found in the nearby Bighorn Mountains, but would only have been accessible and useful for part of the year when the mountains could sustain a hunter-gatherer lifeway. A distance to water cost surface was calculated as the distance to major sources of water in the study area. 
WATER BARRIER

While waterways in other wetter regions were commonly used as transportation, there is little evidence that there was heavy use of the waterways in the PRB prehistorically for transport. The waterways used in this model were addressed as barriers to human travel, rather than conduits. The three Powder Rivers would have been raging rivers in the spring and shallow, slow-moving creeks in the late summer and early fall seasons. Seasonality is much more difficult to assess in a predictive model and it was assumed that waterways would be fairly significant barriers to travel.

\section{TERRAIN RUGGEDNESS INDEX}

Terrain ruggedness can be used as a proxy for or in addition to a slope variable (Bevan and Connolly 2004). Terrain ruggedness estimates how different elevation is within a neighborhood of cells. This method highlights some areas that are perhaps more or less rugged than the slope calculation can differentiate. Based on a detailed visual inspection, the difference between these two variables is significant enough that the terrain ruggedness and slope are both effective variables. In order to calculate the terrain ruggedness for each cell, the difference in elevation from each of the neighboring cells is calculated. Specifically, the equation compares the root-mean-square of the elevation values of each cell and the surrounding eight neighbors, in order to model the ruggedness (difference in values) of the cells (Riley et al. 1999). Thus, if a cell is surrounded by eight cells that are at roughly the same 
elevation, the terrain is classified as smooth. For cells that have a high difference in values from the neighboring cells, the terrain is very rugged.

\section{DISTANCE TO CLINKER DEPOSITS}

Hunter-gatherers were using porcellanite throughout prehistory to form stone tools, used in hunting, gathering, processing, ceremonies, rituals and more (Wagers 2006). Prehistorically in the PRB, porcellanite was available in man-made quarries mined from clinker deposits, which were most likely returned to regularly to replenish stone for tool-making. Local groups would have known the location of the porcellanite outcrops and quarries, and likely camped and sited activity areas with easy access to these procurement locations. The locations of outcrops of clinker deposits were used in this case study as a proxy for the location of porcellanite quarries and outcrops, and these were used to estimate the distance to clinker deposits.

\section{COST SURFACE CREATION}

A cost surface can be defined as an approximation of the amount of effort it would take a person to cross any given pixel in a cost surface raster. Each cell in a cost surface is assigned a value that represents the relative effort of traversing that cell. Cost in this case is a unitless measure. For example, the lower the cost of a cell, the easier it is to walk across. The higher the cost of a cell, the more effort it requires to travel across.

To create a cost surface using all three variables (Slope, Water and Terrain ruggedness), the datasets were reclassified into a common scale. This range is from 
0 to 10 , where 0 represents easy travel (i.e. flat slopes, smooth terrain and no water) and 10 represents difficult travel (i.e. steep slopes, rugged terrain and water obstacles).

Water, in this case, is viewed as a hindrance to direct travel across waterbodies or rivers, and was thus reclassified into two categories: 0 for non-water and 9 for the riverbeds which run within the project area. Slope was calculated using Howey's (2007) methodology, and once calculated was classified into 10 classes using the natural breaks method, with the lowest slope assigned very low values (1-4) because of the ease of traversing flat slopes, and the higher slope values assigned very high values (8-10). Terrain ruggedness was classified using natural breaks into 10 classes. The variables were combined mathematically using a linear combination scheme with differing weights to the variables. In this analysis, terrain ruggedness was weighted at $40 \%(0.40)$, slope at $40 \%(0.40)$ and water at $20 \%$ $(0.20)$. Weights were chosen based on perceived importance of these variables on how human groups would traverse the landscape. Additionally, water as a barrier to travel was given a lighter weight because of its dependence on seasonality - i.e. whether water truly would have created a barrier for mobility.

These three weighted variables were added together, creating one map layer that represents all variables. The range of the combined layer has a theoretic minimum of 2 (the cells had the lowest value for Slope and Terrain Ruggedness) and a maximum of 29 (each cell is calculated as nearly impassable). The results of the linear combination for this project was a scale ranging between 2 and 24, suggesting 
that there are very easy areas to traverse as well as extremely difficult (impassable) areas that probably cannot be traversed (Figure 10).

\section{COST DISTANCE CALCULATION}

Once a cost raster has been created, it can be used as a baseline for estimating how much effort it would require to travel to a destination from any given point within the project area. The two destinations that this project focuses on are the location of clinker deposits, where porcellanite can be found to make stone tools, and water. To estimate the total cost of traveling across the landscape, a cost distance was calculated.

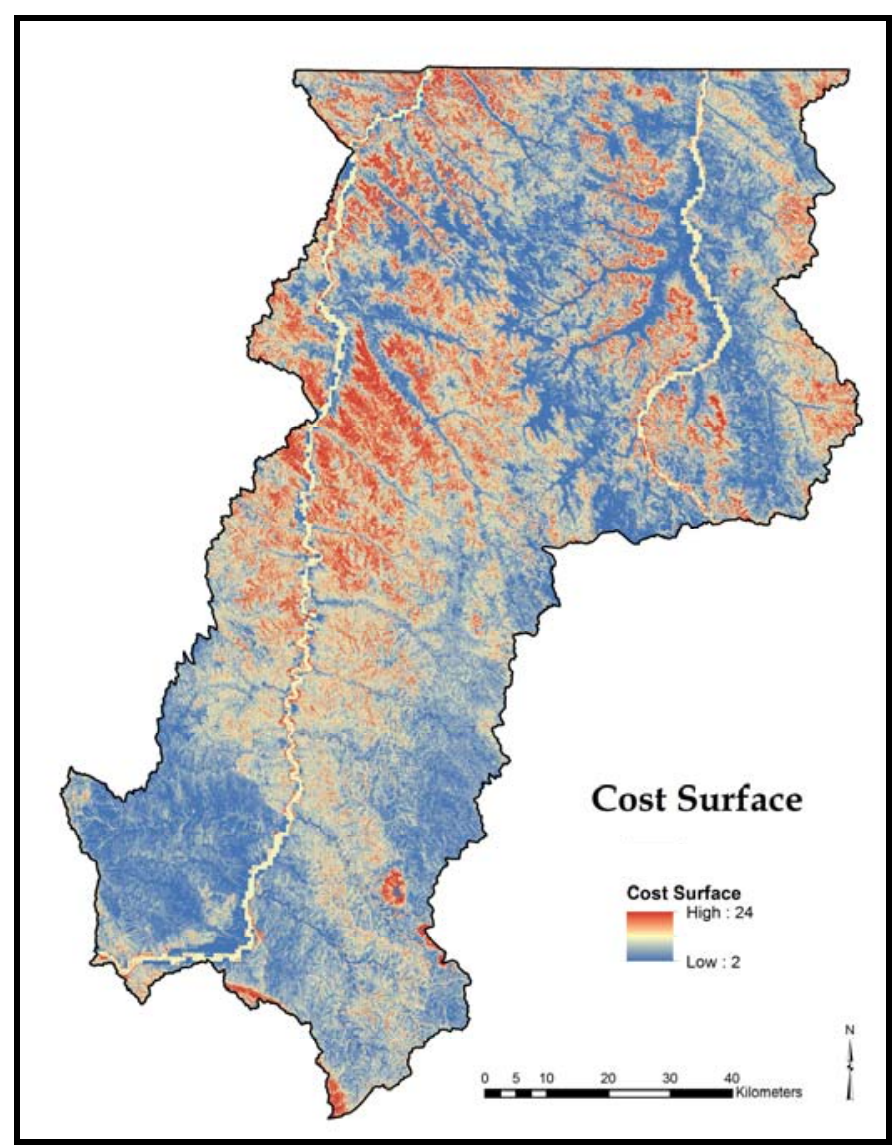

FIGURE 10: CALCULATED COST SURFACE 
The results of the cost distance are in raster dataset format. Essentially, the cell values of the cost distance are the cumulative addition of each cell value away from a resource. For example, if a hypothetical thirsty person walks three cells towards the river, and if each cell has a value of 2, then the hypothetical person will have traveled 6 cost units towards the water $(2+2+2=6)$. However, if there were a cliff between the person and the water, traversing the cliff would make the cost much higher, even though the physical distance may be the same.

In order to compare this result to the location of archaeological sites, a spatial analysis tool was used, which appends a column of the cumulative costweighted distance value of that site location from the resource. Using the example above, the appended column value for a site three pixels from the water would be 6 .

The resulting datasets included a cost distance from water (Water) (Figure 11), a cost distance from clinker deposits (Clinker) (Figure 12) and a cost distance of a combined clinker deposits and water (Combination) (Figure 13), for a total of three finalized cost distance related independent variables. 


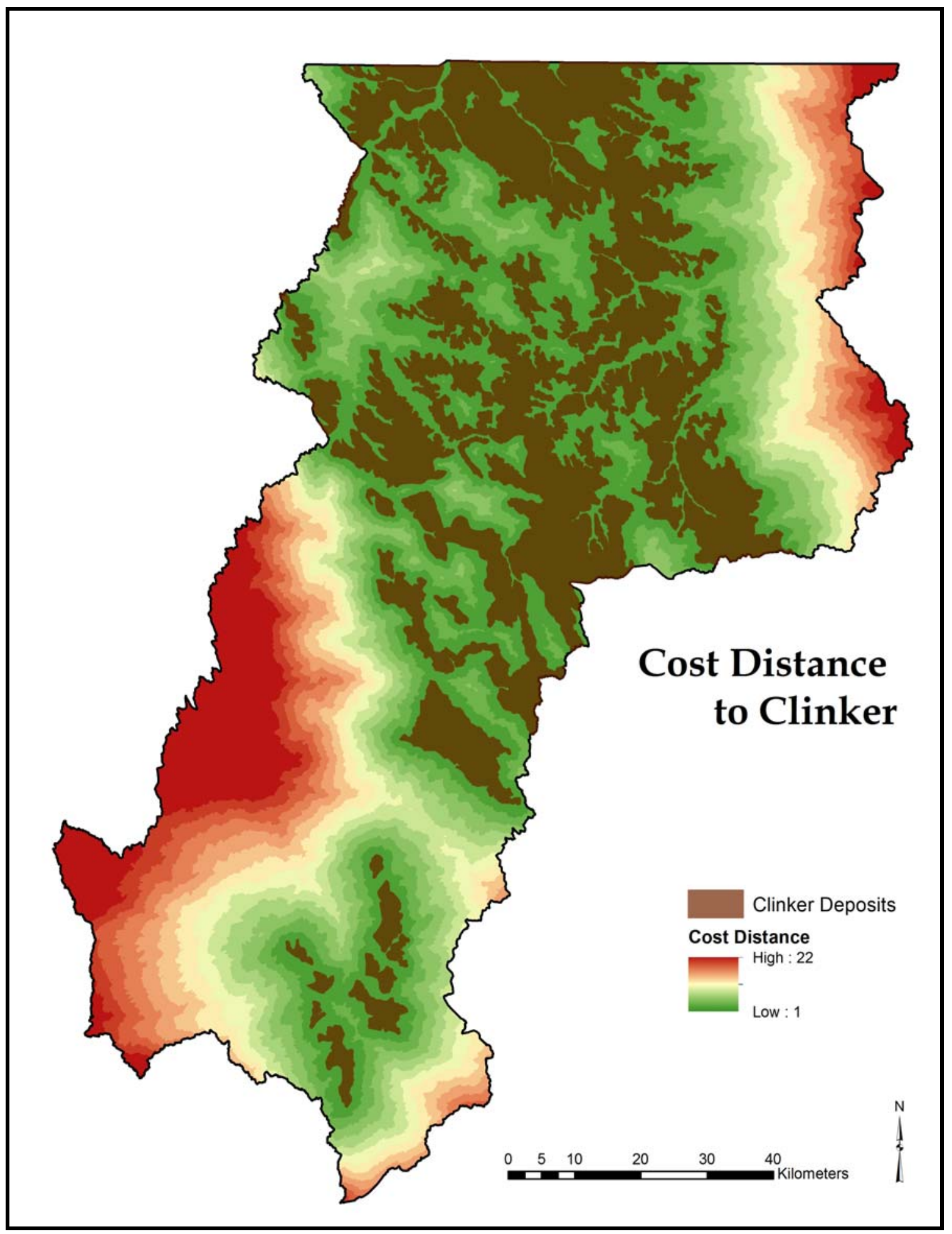

FIGURE 11: COST DISTANCE TO CLINKER DEPOSITS 


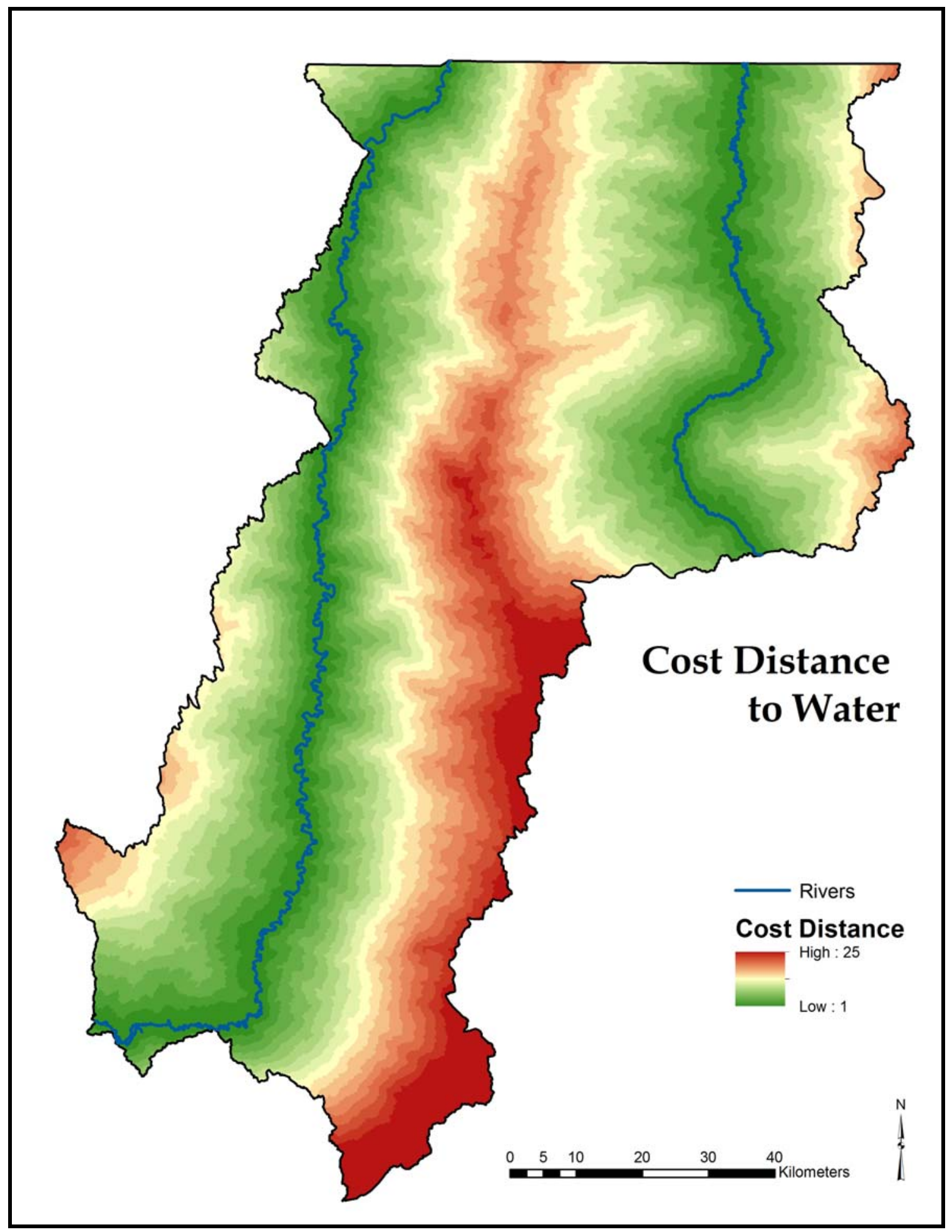

FIGURE 12: COST DISTANCE TO WATER 


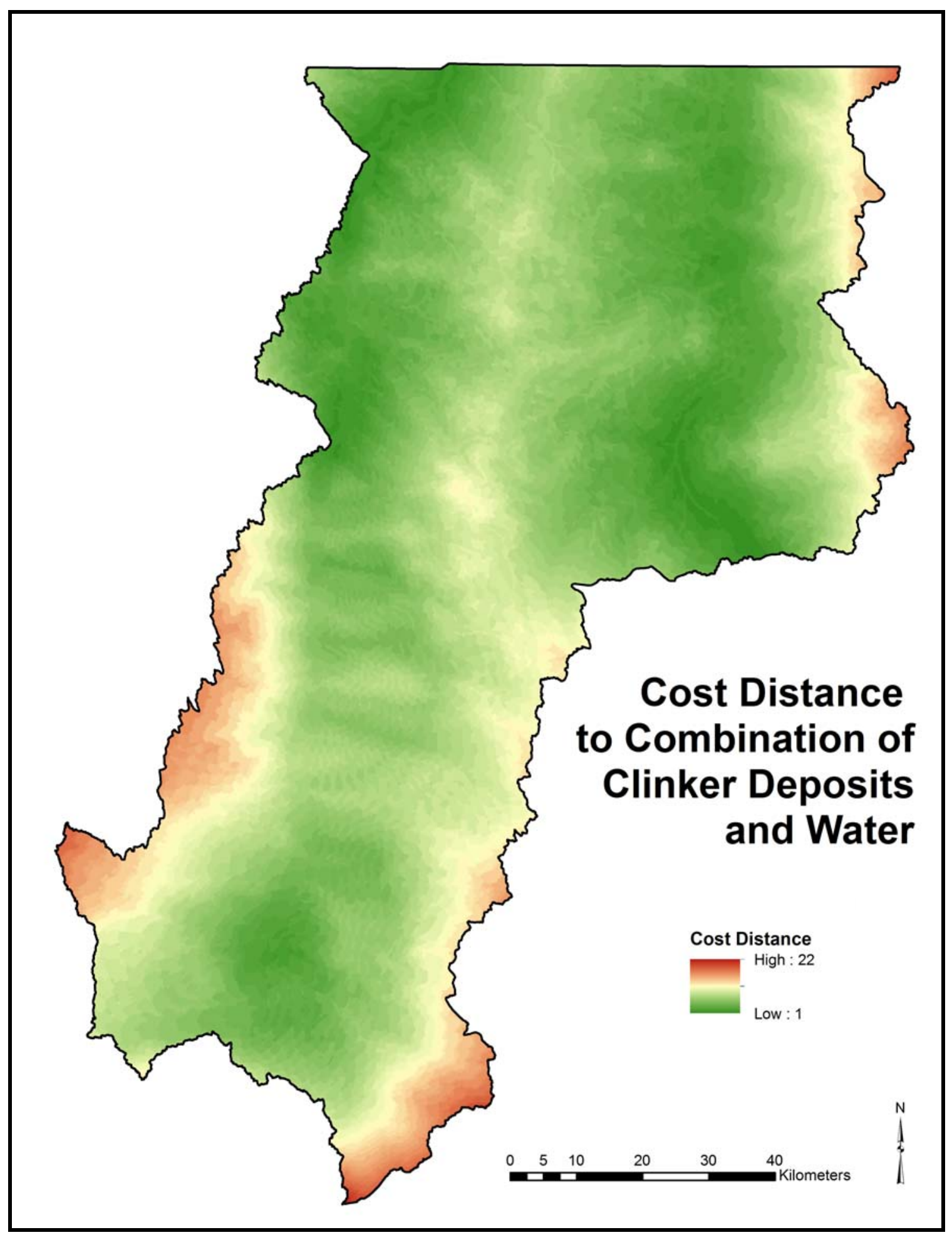

FIGURE 13: COMBINATION COST DISTANCES TO CLINKER AND WATER 


\section{LOGISTIC REGRESSION BY SITE PERIOD}

In order to determine the relationship between archaeological site locations and the cost distances to water and clinker, the polygons of the archaeological sites were converted to points (centroids). A subset of sites for this analysis was chosen based on "site period" which categorizes sites based on the age of artifacts. In this case, the site periods are defined as prehistoric, historic or multi-component (both prehistoric and historic artifacts). Only sites characterized as prehistoric or multicomponent were used in this analysis. For the first set of regression analyses 1602 sites were used, and 1602 non-site random points were created within the same project area for comparison. A 50 meter buffer was used to prevent the sites and non-sites from co-existing at the same location. The 50 meter buffer distance is based on cultural resource guidelines specifying the minimal distance between two archaeological sites.

Three separate binary logistic regression analyses were calculated based on the three cost distance independent variables. The dependent variable in this case was site presence (consisting of true site locations and randomly generated nonsites). Independent variables were the cost distances of Water, Clinker and Combination (Table 2). 
TABLE 2: BINARY LOGISTIC REGRESSION RESULTS

\begin{tabular}{|c|c|c|c|c|c|c|c|}
\hline \multirow{2}{*}{ Regression } & Variables & Method & $\begin{array}{c}\text { Cox \& } \\
\text { Snell R } \\
\text { Square }\end{array}$ & $\begin{array}{c}\text { Nagelkerke } \\
\text { R Square }\end{array}$ & Significance & B & Exp(B) \\
\hline \multirow{3}{*}{$\mathbf{1}$} & Clinker & $\begin{array}{c}\text { Forward } \\
\text { Step }\end{array}$ & 0.006 & 0.008 & 0.000 & 0.034 & 1.035 \\
\cline { 2 - 8 } & Water & $\begin{array}{c}\text { Forward } \\
\text { Step }\end{array}$ & 0.006 & 0.008 & $\mathrm{n} / \mathrm{a}$ & $\mathrm{n} / \mathrm{a}$ & $\mathrm{n} / \mathrm{a}$ \\
\cline { 2 - 8 } & Combination & $\begin{array}{c}\text { Forward } \\
\text { Step }\end{array}$ & 0.006 & 0.008 & $\mathrm{n} / \mathrm{a}$ & $\mathrm{n} / \mathrm{a}$ & $\mathrm{n} / \mathrm{a}$ \\
\hline \multirow{2}{*}{$\mathbf{2}$} & Water & Enter & 0.007 & 0.009 & 0.000 & -0.034 & 0.966 \\
\cline { 2 - 9 } & Combination & Enter & 0.007 & 0.009 & 0.000 & 0.034 & 1.035 \\
\cline { 2 - 9 } & Slope & Enter & 0.007 & 0.009 & 0.963 & 0.000 & 1.000 \\
\hline $\mathbf{3}$ & Combination & Enter & 0.002 & 0.002 & 0.022 & -0.011 & 0.989 \\
\hline
\end{tabular}

\section{LOGISTIC REGRESSION BY SITE TYPE}

A second subset of sites was selected based on "site types". The WYCRIS database of site locations and attributes was classified by "site type", rather than "site period." The "site type" attribute categorizes sites based on the specific type of artifacts documented at the site (i.e. cairns, tipi rings, lithic scatters, etc.). The sites were culled into 11 site type categories (Table 3). Each site type was regressed against an equal sized sample of non-sites.

\section{TABLE 3: SITE TYPES AND BINARY LOGISTIC REGRESSION RESULTS}

\begin{tabular}{|c|l|c|c|c|c|c|c|}
\hline \multicolumn{4}{|c}{ Sites } & \multicolumn{4}{c|}{ Statistics } \\
\hline $\begin{array}{c}\text { Type } \\
\text { Code }\end{array}$ & \multicolumn{1}{|c|}{ Type } & $\begin{array}{c}\text { Sample } \\
\text { Size }\end{array}$ & $\begin{array}{c}\text { Random } \\
\text { Points }\end{array}$ & $\mathbf{R}^{2}$ & $\begin{array}{c}\text { Hosmer/ } \\
\text { Lemeshow }\end{array}$ & $\begin{array}{c}\mathbf{H} / \mathbf{L} \\
\mathbf{C h i}^{2}\end{array}$ & $\begin{array}{c}\text { Overall } \\
\text { Prediction }\end{array}$ \\
\hline 3 & Cairn/ Rock Alignment & 21 & 21 & 0.085 & 0.347 & 8.960 & 64.3 \\
\hline 4 & Hearth/Firepit & 256 & 256 & 0.295 & 0.000 & 30.531 & 73.0 \\
\hline 5 & Lithic Scatter & 900 & 900 & 0.097 & 0.366 & 8.731 & 60.4 \\
\hline 8 & Habitation/ Occupation & 271 & 271 & 0.264 & 0.382 & 8.544 & 68.8 \\
\hline 11 & Stone Rings & 96 & 96 & 0.272 & 0.000 & 32.774 & 67.7 \\
\hline 15 & Lithic Quarry & 30 & 30 & 0.514 & 0.013 & 19.320 & 83.3 \\
\hline 16 & Milling/ Processing & 23 & 23 & 0.463 & 0.138 & 11.024 & 69.6 \\
\hline All & All Sites & 1602 & 1602 & 0.090 & 0.065 & 14.696 & 61.4 \\
\hline
\end{tabular}


The binary logistic regression analyses conducted for these site type categories included the Clinker, Water and Combination variables described above. They also included individual variables in order to determine whether a statistical correlation existed with any individual variable outside of a cost distance calculation (Table 4).

TABLE 4: SITE TYPES AND SIGNIFICANCE OF VARIABLES

\begin{tabular}{|r|l|c|c|c|c|c|c|c|}
\hline \multicolumn{3}{|c|}{ Sites } & \multicolumn{5}{c|}{ Statistical Significance of Variables } \\
\hline $\begin{array}{r}\text { Type } \\
\text { Code }\end{array}$ & \multicolumn{1}{|c|}{ Type } & $\begin{array}{c}\text { Sample } \\
\text { Size }\end{array}$ & $\begin{array}{c}\text { Random } \\
\text { Sample }\end{array}$ & Elevation & Slope & $\begin{array}{c}\text { Terrain } \\
\text { Ruggedness }\end{array}$ & $\begin{array}{c}\text { Cost } \\
\text { Water }\end{array}$ & $\begin{array}{c}\text { Cost } \\
\text { Clinker }\end{array}$ \\
\hline 3 & Cairn/ Rock Alignment & 21 & 21 & 0.686 & 0.929 & 0.450 & 0.668 & 0.940 \\
\hline 4 & Hearth/Firepit & 256 & 256 & 0.000 & 0.200 & 0.231 & 0.000 & 0.105 \\
\hline 5 & Lithic Scatter & 900 & 900 & 0.000 & 0.019 & 0.341 & 0.000 & 0.907 \\
\hline 8 & Habitation/ Occupation & 271 & 271 & 0.007 & 0.206 & 0.175 & 0.000 & 0.000 \\
\hline 11 & Stone Rings & 96 & 96 & 0.948 & 0.011 & 0.014 & 0.000 & 0.042 \\
\hline 15 & Lithic Quarry & 30 & 30 & 0.270 & 0.115 & 0.052 & 0.002 & 0.991 \\
\hline 16 & Milling/ Processing & 23 & 23 & 0.114 & 0.255 & 0.552 & 0.004 & 0.074 \\
\hline All & All Sites & 1602 & 1602 & 0.032 & 0.093 & 0.000 & 0.000 & 0.289 \\
\hline
\end{tabular}

\section{RESULTS}

Logistic regression of site periods and non-sites with the three independent variables (clinker, water and combination) show no correlation between variables. These results are most likely due to the lack of distinction between prehistoric time periods; without separation between different eras of human occupation throughout the PRB, it is difficult to isolate distinctions between the Paleo-Indian period from the Archaic period, for example. Because of the large sample size and the time "smear" across the entirety of the Holocene, the results show a substantial lack of fit - meaning that the independent variables are not particularly good at predicting the location of archaeological sites. Most likely, a combination of smaller 
sample size and carefully chosen archaeological sites based on artifact content and age would allow for a higher correlation of sites and independent variables.

The results of the site type categories are more nuanced but suggest a substantial lack-of-fit based on high $\mathrm{Chi}^{2}$ values. The significance values suggest a correlation (the lower the value, the higher the correlation) and a few of the $\mathrm{R}^{2}$ values are moderately high $(0.514)$. However the analysis does not statistically describe a relationship between site type categories and each of these variables. At best, this analysis shows that $51.4 \%$ of lithic quarry sites can be explained by the independent variables, although the high $\mathrm{Chi}^{2}$ value suggests that recalibration of the model is needed. While the results show slightly better correlation between site types and the independent variables than results of the site period above, overall the model still shows a lack of fit. Clearer results may result from a reorganization of the archaeological site database in order to flesh out time period differences between human occupation sites.

\section{DISCUSSIONS}

There are a number of limitations of the datasets and analysis that will be described below.

As part of the methodology of this case study, the surface areas of the archaeological sites were converted to single points. This was necessary because the calculations involved in cost distance do not easily support areas (polygons). The calculation to compute the centroid of the site polygon can alter the location of the site dramatically, particularly if the site spreads over a large surface area. One 
method of minimizing this potential for error is to use feature locations or activity areas within the site boundary, rather than generalizing the site to a centroid.

Archaeological site recording methodology has changed significantly over the last 100 years. The types in information recorded, the level of detail and the surrounding terrain description have all changed over time. In the early days of site recording, a brief sentence or two was written down describing very vague locational and artifact data. Over the course of the 20th century, more detailed descriptions and locations were recorded, culminating in the current official SHPO archaeological site forms. A parallel development over this time frame was the development of a standard definition of number of artifacts and area which defines an archaeological site. In the early 20th century, there were no guidelines determined for determining an archaeological site. Currently, the Wyoming SHPO has determined that the definition of an archaeological site is 10 pieces of cultural material within a 30 meter diameter area. Anything less than that is considered an archaeological isolated find. All of these factors taken together result in highly inconsistent database attributes which is difficult to use for GIS analysis. Limiting the sites by the year that they were recorded (i.e. only using sites recorded during or after the year 2000) could eliminate some of the inconsistencies.

Another inconsistency issue affecting this case study is the actual known location of each archaeological site. Although a site may have a description, locational data is rarely ground-truthed unless a new project happens to occur at the same location. Sites from the beginning of the 20th century were vaguely 
described and rarely ground-truthed. Sometimes the materials located there were collected, in which case finding the site again is virtually impossible. Prior to functional GPS data, locations of archaeological sites were described using Public Land Survey Systems (PLSS) descriptions. These areas are large and sometimes inaccurate. Since the advent of usable GPS data, the locational information for archaeological sites has improved greatly. This has improved even more since Selective Availability (military scrambling of GPS satellite signals) ended in 2000.

A further limitation of the archaeological site dataset involves the basic organization of the Wyoming SHPO database. The current organization does not include any data regarding artifacts or types of artifacts other than "period" (historic, prehistoric or multi-component) and "type" (which is populated with various categories, of which few are standardized). No diagnostic data is readily available, which could potentially help date the archaeological site to a period in prehistory. Ideally, a reorganization of the database would involve adding a possible date or date range per site, including the year recorded per site, and listing diagnostic artifacts located at the site. Combining the written site records and documentation with the database would have taken a prohibitive amount of hours to complete, and so was not conducted as part of this case study. However if this was completed at some future date, the usefulness of this dataset would be greatly enhanced, and could yield more positive correlative results during analysis (Table 5). 
TABLE 5: EXAMPLE OF WYOMING SHPO DATABASE ORGANIZATION

\begin{tabular}{|c|c|c|c|l|}
\hline State & County & STNO & \multicolumn{1}{|c|}{ PERIOD } & \multicolumn{1}{|c|}{ TYPE } \\
\hline 48 & NA & 2360 & HISTORIC & HISTORIC OTHER \\
\hline 48 & SH & 657 & PREHISTORIC & $\begin{array}{l}\text { PREHISTORIC LITHIC SCATTER/ CHIPPING/ } \\
\text { KNAPPING STATION }\end{array}$ \\
\hline 48 & SH & 749 & PREHISTORIC & $\begin{array}{l}\text { PREHISTORIC LITHIC SCATTER/ CHIPPING/ } \\
\text { KNAPPING STATION }\end{array}$ \\
\hline 48 & SH & 750 & PREHISTORIC & $\begin{array}{l}\text { PREHISTORIC LITHIC SCATTER/ CHIPPING/ } \\
\text { KNAPPING STATION }\end{array}$ \\
\hline 48 & SH & 647 & PREHISTORIC & $\begin{array}{l}\text { PREHISTORIC FEATURE - HABITATION - } \\
\text { ALIGNMENTS }\end{array}$ \\
\hline 48 & SH & 1064 & MULTICOMPONENT & $\begin{array}{l}\text { PREHISTORIC ARTIFACTS AND FEATURES - } \\
\text { HABITATION - STONE RINGS }\end{array}$ \\
\hline 48 & SH & 1107 & PREHISTORIC & OPEN CAMP, OCCUPATION \\
\hline 48 & SH & 1201 & MULTICOMPONENT & OPEN CAMP, OCCUPATION \\
\hline 48 & SH & 908 & PREHISTORIC & $\begin{array}{l}\text { PREHISTORIC LITHIC SCATTER/ CHIPPING/ } \\
\text { KNAPPING STATION }\end{array}$ \\
\hline 48 & BH & 3595 & PREHISTORIC & ROCK ALIGNMENTS - CEREMONIAL \\
\hline
\end{tabular}

Using clinker deposits as a proxy for porcellanite quarry locations or outcrops is an inherent limitation in this analysis. Clinker deposits have been mapped accurately across the PRB for use in siting mine locations. However, the locations of clinker deposits are not an assurance of the location of porcellanite outcrops. Most likely, certain quarry sites were of a higher quality for the creation of stone tools, more readily accessible without intensive manual labor to unearth large nodules, or in large enough quantities to provide stone for many tools. This information is not readily available without expensive and intensive cultural survey of the area specifically to record quarry locations and outcrops. If this information were available, it would no doubt profoundly reshape the results of this research.

\section{FUTURE RESEARCH}

One of the primary objectives for use of the Wyoming SHPO database in future research efforts should be the reorganization and addition of new information to the archaeological site dataset. Including diagnostic tools or artifacts 
and associated period of prehistory would greatly improve the usefulness of this dataset, and potentially lead to a solid predictive model of archaeological site location.

The inclusion of prehistoric climate models can also improve the results of research similar to this case study. By modeling past climatic conditions in concert with the archaeological materials of specific time periods, much more complex questions can be asked about hunter-gatherer mobility and land use. An analysis of soil and plant databases to determine whether clinker deposits are associated with common plants or types of soil could be useful in furthering this research, as well. 


\section{Chapter 5: Conclusions}

The Powder River Basin is currently an extremely important economic force in the coal, oil and gas economy of Wyoming and the United States. The sheer number of strip mines, oil and gas extraction fields, oil and gas pump stations and other associated impacts is enormous in comparison to other resource-rich mining areas. This development poses a direct threat to cultural resources, particularly in light of the close association of archaeological sites with clinker deposits in the area. Any archaeological sites must be identified, documented in detail and determined eligible or ineligible to the National Register of Historic Places (NRHP). If eligible, federal law requires that adverse impacts be avoided or mitigated if avoidance is not possible. If ineligible, they are afforded no consideration under federal law. Finding sites through field surveys is costly, and generally does not happen until an area has been selected for use. However, if a technique existed which would highlight zones which are most likely have a high percentage or probability of archaeological sites, these areas could be addressed by extraction companies during the early planning stages to determine ways to avoid adversely impacting cultural resources while pursuing alternative methods or locations of natural resource extraction.

Concerns for the human landscapes of the past and the potential jeopardy that our current activities in this area pose to them have driven this research. Laws governing the discovery and documentation of prehistoric landscapes and artifacts are in place to protect these resources. However, any method or technique that can 
be helpful in preserving these resources deserves to be tested and implemented if successful. In light of this conflict, this research has demonstrated a predictive modeling technique that can help with addressing the federal requirements for CRM in the Powder River Basin of Wyoming. Since the federal requirements are intensive in this area, particularly with the growth of heavy industry, the usefulness of the SHPO database cannot be overstated. The reorganization of the archaeological database would offer a solution for some of the limitations noted during this research, including the archaeological site recording techniques and information, changes over time in state and federal regulations, and changing definitions of archaeological sites. A restructuring of the database would easily support culling sites from particular "phases" of archaeological site recording (minimizing error), and would most likely yield compelling evidence of a statistical relationship between clinker deposits and the location of prehistoric archaeological sites. Other limitations, such as using clinker as a proxy for porcellanite quarry locations, are perhaps best addressed with field work and ground-truthing outcrops and quarry locations.

This case study yielded some statistical correlations between archaeological sites and clinker deposits, water and elevation. However, as currently constructed, it remains an unrefined model that would require additional reorganization of the Wyoming SHPO database to be more effective; however, this research has taken a solid first step towards identifying important statistical relationships. Should these relationships be fleshed out in the future, I believe the results would be 
exceptionally helpful in diminishing conflicts between the federal requirements, private interest and preservation of cultural resources in the Powder River Basin. 


\section{References}

36 CFR 800, "Protection of Historic Properties," Code of Federal Regulations. Available at: www.achp.gov/regs-rev04.pdf

Author unknown.

2010. Bureau of Land Management Wyoming Annual Report. State of Wyoming. http://www.blm.gov/pgdata/etc/medialib/blm/wy/information/annualrep orts.Par.59860.File.dat/2010anrpt.pdf. Accessed on January 12, 2012.

2012. Bureau of Land Management, Wyoming. The Checkerboard. http://www.blm.gov/wy/st/en/programs/nlcs/Continental Divide/ckrbrd. html. Accessed on January 12, 2012.

Aldenderfer, Mark and Herbert Maschner. 1996. Anthropology, Space and Geographic Information Systems. New York: Oxford University Press.

Arakawa, Fumiyasu and Christopher Nicholson. 2008. Early Commuting: Exploring the Mobility of Prehistoric People. ArcUser: The Magazine for ESRI Software Users. 11(3): 30-31.

Banks, William et. al. 2009. Investigating links between ecology and bifacial tool types in Western Europe during the Last Glacial Maximum. Journal of Archaeological Science 36: 2853-2867.

Bevan, Andrew and James Conolly. 2004. GIS, Archaeological Survey, and Landscape Archaeology on the Island of Kythera, Greece. Journal of Field Archaeology 29(1/2): 123 - 138.

Brandt, Roel, Bert Groenewoudt and Kenneth Kvamme. 1992. An experiment in archaeological site location: modeling in the Netherlands using GIS techniques. World Archaeology 24(2): 268-282.

Brewster, A., B.F. Byrd, and S.N. Reddy. 2003. Cultural landscapes of coastal foragers: An example of GIS and drainage catchment analysis from Southern California. Journal of GIS in Archaeology 1: 46-60.

Burroughs, William J. 2005. Climate Change in Prehistory: The End of the Reign of Chaos. Cambridge, UK: Cambridge University Press.

Conolly, James and Mark Lake. 2006. Geographical Information Systems in Archaeology. New York: Cambridge University Press.

Considine, Timothy. 2009. Powder River Basin Coal: Powering America. Final Report to the Wyoming Mining Association.

Duncan, Richard and Kristen Beckman. 2000. The Application of GIS Predictive Site Location Models within Pennsylvania and West Virginia. Practical Applications in 
GIS for Archaeologists edited by Konnie Westcott and R. Joe Brandon. pp. 33-58. New York, NY: Taylor and Francis.

Espa, G., R. Benedetti, A. De Meo, U. Ricci and S. Espa. 2006. GIS based models and estimation methods for the probability of archaeological site location. Journal of Cultural Heritage 7(3): 147-155.

Fitzgerald, Timothy. 2011. The Role of Split Estate in Environmental Performance of Coalbed Methane Development. Unpublished. University of Maryland.

Fowler, Don. 1982. Cultural Resources Management. Advances in Archaeological Method and Theory 5: 1-50.

Frison, George C.

1991. Prehistoric Hunters of the High Plains $2^{\text {nd }}$ ed. San Diego, CA: Academic Press Inc.

1998. The Northwestern and Northern Plains Archaic in Archaeology on the Great

Plains edited by W. Raymond Wood. Pp. 140-166. Lawrence, KS: University of Kansas Press.

Hardesty, Donald and Barbara Little. 2009. Assessing Site Significance. Lanham, MD: Altamira Press.

Heffern, Edward, Peter Reiners, Charles Naeser and Donald Coates. 2007. Geochronology of clinker and implications for evolution of the Powder River Basin landscape, Wyoming and Montana. Reviews in Engineering Geology 18: 155-175.

Howey, Meghan. 2007. Using multi-criteria cost surface analysis to explore past regional landscapes: a case study of ritual activity and social interaction in Michigan, AD 1200-1600. Journal of Archaeological Science 34(11): 1830-1846.

Huang, Shawn, Anthony Alvarado, Lyle Zevenbergen, and John Cochran. 2011/2012. Assessing the Success of Surface Coal Mine Reclamation: Innovative GIS Tool Automates Watershed Erosion Modeling. ArcNews Winter 2011/2012: 26-27.

Kelly, Robert. 1995. The Foraging Spectrum: Diversity in Hunter-Gatherer Lifeways. Washington D.C.: Smithsonian Institution.

King, Thomas F. 2008. Cultural Resource Laws and Practice: An Introductory Guide ( $3^{\text {rd }}$ Ed.). Walnut Creek, CA: AltaMira Press.

Kohler, Timothy and Sandra Parker. 1986. Predictive Models for Archaeological Resource Location. Advances in Archaeological Method and Theory Vol 9. pp. 397452. New York: Academic Press. 
Krist, F. and Brown, G. 1994. GIS modeling of Paleo-Indian Period Caribou Migrations and Viewsheds in Northeastern Lower Michigan. Photogrammetric Engineering and Remote Sensing, 60(9): 1129-1137.

Kvamme, Kenneth. 1982. Methods for analyzing and understanding hunter-gatherer site location as a function of environmental variation. Paper presented at the $47^{\text {th }}$ Annual Meeting of the Society for American Archaeology. Minneapolis, MN.

Lipe, William D. 1984. Value and meaning in cultural resources. Approaches to the archaeological heritage: a comparative study of world cultural resource management systems (New Directions in Archaeology Series), Edited by Henry Cleere. Cambridge, UK: Cambridge University Press.

Llobera, Marcos. 2007. Reconstructing Visual Landscapes. World Archaeology 39(1):51-69.

McCoy, Mark and Thegn Ladefoged. 2009. New Developments in the Use of Spatial Technology in Archaeology. Journal of Archaeological Research 17:263-295.

McManamon, Francis P. 2000. The protection of archaeological resources in the United States: reconciling preservation with contemporary society. Cultural Resource Management in Contemporary Society: Perspectives on Managing and Presenting the Past Edited by Francis McManamon and Alf Hatton. New York, NY: Routledge.

McNab, W. Henry and Peter E. Avers. 1994. Chapter 41: Powder River Basin. Ecological Subregions of the United States. WO-WSA-5. Regional compilers and ECOMAP Team of the Forest Service. United States Forest Service Publication.

Mehrer, Mark and Konnie Westcott. 2006. GIS and Archaeological Site Location Modeling. Boca Raton, FL: Taylor and Francis.

Miller, James C. 1991. Lithic Resources (Chapter 12). Prehistoric Hunters of the High Plains, $2^{\text {nd }}$ ed. Edited by George Frison. San Diego, CA: Academic Press Inc.

National Historic Preservation Act of 1966, 16 U.S.C. 470, et seq. http://www.achp.gov/NHPA.pdf. Accessed on January 14, 2012.

Riley, S.J., S.D. DeGloria, and R. Elliot. 1999. A terrain ruggedness index that quantifies topographic heterogeneity. Intermountain Journal of Sciences 5(1-4).

Rogerson, Peter A. 2006. Statistical Methods for Geography: A Student's Guide (2nd. Ed.). California: SAGE Publications Ltd. 
Rua, H. 2009. Geographic information systems in archaeological analysis: a predictive model in the detection of rural Roman villae. Journal of Archaeological Science 36(2):224-235.

Stern, Walter E. and Lynn H. Slade. 1995. Effects of Historic and Cultural Resources and Indian Religious Freedom on Public Lands Development: A Practical Primer. Natural Resources Journal 35(1): 133-183.

Stracher, Glenn B. 2007. Geology of Coal Fires: Case Studies from Around the World. Boulder, CO: Geological Society of America.

Straube, Michele and Melinda Holland. 2003. A Conflict Assessment of Split Estate Issues and a Model Agreement Approach to Resolving Conflicts Over Coalbed Methane Development in the Powder River Basin. Unpublished Conflict Assessment Report prepared for U.S. Institute for Environmental Conflict Resolution. Available online: http://www.ecr.gov/pdf/CAR.pdf (Accessed January 28, 2012).

Swindell, Gary S. 2007. Powder River Basin Coalbed Methane Wells - Reserves and Rates. Paper presented at 2007 Society of Petroleum Engineers Rocky Mountain Oil and Gas Technology Symposium (SPE 107308). Denver, Colorado. 16-18 April 2007.

Taliaferro, Matthew et. al. 2009. Obsidian procurement, least cost path analysis, and social interaction in the Mimbres area of southwestern New Mexico. Journal of Archaeological Science Article in Press (doi: 10.1016/j.jas.2009.10.018).

Tewalt, Susan, Leslie Ruppert, Linda Bragg, Richard Carlton, David Brezinski, Rachel Wallack and David Butler. 2000. Chapter C: A Digital Resource Model of the Upper Pennsylvanian Pittsburgh Coal Bed, Monongahela Group, Northern Appalachian Basin Coal Region. United States Geological Survey Professional paper 1625-C.

Thacker P.T. 2006. Local Raw Material Exploitation and Prehistoric Hunter-Gatherer Mobility. Archaeology and Ethnoarchaeology of Mobility. Eds. F. Sellet, R. Greaves and P.L. Yu. Pp. 240-261.

Verhagen, Phillip. 2007. Case Studies in Archaeological Predictive Modeling. Netherlands: Lieden University Press.

Wagers, Scott J. 2006. Fidelity: Cultural Resource Investigations in the East Decker Mine Permit Area, Big Horn County, Montana. Prepared by Ethnoscience, Inc. for Fidelity Exploration and Production Company.

Warren, Robert and David Asch. 2000. A Predictive Model of Archaeological Site Location in the Eastern Prairie Peninsula. Practical Applications in GIS for 
Archaeologists edited by Konnie Westcott and R. Joe Brandon. pp. 5-32. New York, NY: Taylor and Francis.

Wheatley, David and Mark Gillings. 2002. Spatial Technologies and Archaeology. New York, NY: Taylor and Francis.

Wood, W. Raymond ed. 1998. Archaeology on the Great Plains. Lawrence, KS: University of Kansas Press. 